NBSIR 83-2775(R)

\title{
Conference on Standards, Measurements, Quality Control and Production for Economic Support and Growth
}

A Record of the U.S. Papers to be Presented at the Conference on Standards, Measurements, Quality Control and Production for Economic Support and Growth to be held in Cairo, Egypt, October 29-31, 1983.

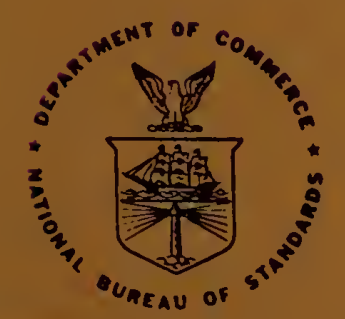



$\cdots$

CONFERENCE ON STANDARDS. MEASUREMENTS, QUALITY CONTROL AND PRODUCTION FOR ECONOMIC SUPPORT AND GROWTH

(A Record of the U.S. Papers to be Presented at the Conference on Standards, Measurements, Quality Control and Production for Economic Support and Growth to be held in Cairo, Egypt, October 29-31, 1983)

\section{U.S. Papers:}

Ernest Ambler, Director, National Bureau of Standards (NBS) Charles G. Culver, Chief, Structures Division, NBS

Richard Goodemote, Chairman of the Board, American Society for Testing and Materials (ASTM)

John L. Donaldson, Deputy Director, Office of Product Standards Policy, NBS

Richard Ronk, Deputy Director, Bureau of Foods, Food and Drug Administration Jack E. Snell, Director, Center for Fire Research, NBS S. D. Rasberry, Acting Chief, Standard Reference Materials, NBS Kurt F. J. Heinrich, Chief, Office of International Relations, NBS

October 1983

The conference is conducted as part of the program under the U.S./NBS Agency for International Development, PASA EGY-0016, Applied Science and Technology Research Project 263-0016. 

FOREWORD

Within the framework of the Applied Science and Technology Research Program between the Governments of Egypt and of the United States of America, the National Bureau of Standards (NBS) is executing a program of assistance to Egyptian Standards organizations. The NBS program is financed under a Participating Agency Service Agreement (PASA) between the United States Agency for International Development (AID) and the National Bureau of Standards. The Egyptian organizations involved are the Egyptian National Institute for Standards (NIS), under the Egyptian Academy of Scientific Research and Technology, and the Egyptian Organization for Standardization and Quality Control (EOS), which is a dependency of the Ministry of Industry of the Egyptian Government. Through NIS, we also interact with the Assay and and Weights Administration, which is under the Weights and Measures Service of the Ministry of Supply and Trade.

The aim of this program is to strengthen systems of measurement, calibration, standards and quality control in Egypt and to promote the research in metrology on which these activities are based. But to translate the progress being achieved in the Egyptian institutions into changes beneficial to the economy and productiveness of Egypt, we must ensure that the services of these institutions are fully known, recognized and utilized by the industries.

To promote such interaction we have organized, for Egyptian industrial management, a Conference entitled "Standards, Measurements Quality Control and Production for Economic Support and Growth" to be held at the Meridien Hote1, Cairo, October 29-31, 1983. The contributions by U.S. speakers to this Conference are reproduced here. We hope that this Conference and publication will achieve their aim to make our viewpoints on the value of measurement and standardization services known to the intended audience, as well as to those in other developing countries that pass through a similar development stage as Egypt. 
Page

I. Papers

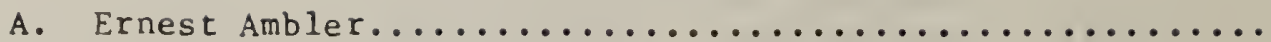

"Role of the National Bureau of Standards in

Standardization and Measurement for USA Industry"

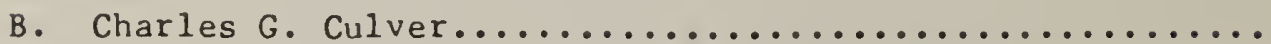

"Building Technology - From Research to Practice"

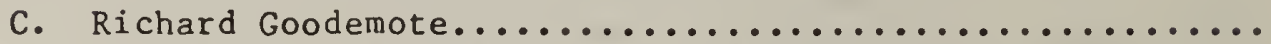

"Private Industry's View of Standards and Certification"

D. John L. Donaldson.

"The Role of National Standards Bodies in Standards and Trade"

E. Richard Ronk...............................

"Food Standards and Quality Assurance Programs at the Food and Drug Administration"

F. Jack E. Snell.............................

"Fire Research"

G. S. D. Rasberry...............................

"The Importance of Standard Reference Materials to Industrial Quality Control"

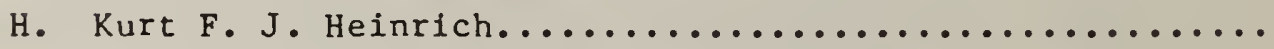

"International Programs of the U.S. National Bureau of St and ards"

II. Appendix I, Public Law 93-498, National Fire Losses.........

III. Appendix II, Fire Risk Analysis.................... 
Role of the Nationa1 Bureau of Standards

in Standardization and Measurement for USA Industry

\author{
Ernest Ambler \\ Director \\ National Bureau of Standards \\ Washington, D.C. 20234
}

The theme of this conference, the role of measurement and standards in a nation's economy, is an important one. The connection between measurement capability and industrial growth, which seems so obvious when we examine the past, can easily be forgotten when we plan for the future. Some of the earliest and most impressive expressions of the importance of measurement were here in Egypt in the precise construction of the ancient pyramids, the early measurements of the Nile levels to predict planting times, and the measurement of grain to plan for the country's survival in the event of crop failure. Many historians have noted that countries with reliable, precise measurements have often developed as world centers of trade and commerce.

Today's industrialized economies depend more than ever on measurements. A nation must be able to manufacture precise sophisticated products with high accuracy, and these products must be compatible with those of the rest of the world. International trade requires international standards; no nation can afford to develop its own system out of step with the rest of the world. Engine blocks made in Egypt must fit other parts of the car made in Europe. To compete in the international market, every industrialized country must maintain a reliable system of measurements and must ensure that these measurements are compatible with international standards.

In the United States the responsibility for establishing and maintaining such a measurement system lies with the National Bureau of Standards. We provide the basic national standards for the country and maintain a link between them and the international standards. The United States and Egypt are both signatories to the Treaty of the Meter. This treaty established the International Bureau of Weights and Measures, a central international standards laboratory in France. The treaty also sets up the mechanism by which international standards can be established, maintained, and changed. Just a few days ago, I represented the United States at the 17 th General Conference of Weights and Measures in Paris; Egypt was represented at this conference by my good friend, Dr. Abde1-Fattah Dawoud.

The National Bureau of Standards was created by an Act of Congress, known as the NBS Organic Act, in March 1901. The United States recognized an increasing need in commerce and industry for measurement standards, test methods, and reliable data. We saw the importance of the basic science that underlies these standards and measurements, and we created a Federal laboratory to meet these needs. In essence, NBS is the central national Laboratory for measurement science. Other countries, for example Germany and Great Britain, had already taken similar actions and many were to follow later on. 
Up until 1904, the Bureau was principally concerned with establishing fundamental standards and planning basic research programs. But the great Baltimore fire in February of that year sharply reminded the Bureau staff of its responsibilities in the field of commercial standards. Fire units first from nearby counties and then from New York, Philadelphia, and Harrisburg arrived in Baltimore only to discover that because of differences in the threads, their hoses could not be coupled with one another or fitted to the local hydrants. The National Bureau of Standards was asked to investigate, and in 1905, the National Fire Protection Association adopted a standard hose coupling.

The war years between 1917 and 1919 made a different kind of demand on the Bureau. Faced with the fact, for example, that 65 percent of our raw wool came from abroad and that millions of uniforms and blankets would be needed for the American armies, the military appealed to the Bureau for help. To find out the characteristics that a wool substitute must have, we set up a small experimental wool manufacturing plant to make the necessary tests. Working the raw materials with available laboratory equipment, we found that the heat-retaining properties of wool depend less on the instrinsic properties of their fibers than on their arrangement, and that a lightweight cotton could be made into almost as warm a fabric as wool.

Throughout our history, we have responded to the technological needs of the United States. Perhaps the most striking change in measurement techniques in recent years has been the introduction of automation. Imperfections of a measurement system no longer need to be compensated for by tuning and trimming. Rather, measurements can be made, and corrections then applied by the computer. Tedious and extremely fine mechanical adjustments have given way to the act of entering instructions on a keyboard. Electronic servo loops have replaced manual adjustments. The result is high accuracy and more consistent performance. Measurements can be repeated often enough to create a sound statistical basis for uncertainty statements.

Now that the economy of Egypt has rapidly industrialized, authorities in your country are also recognizing the need to strengthen the ability to measure and to relate to international standards. To illustrate some of the contributions that measurements and standards can make, I would like to describe for you briefly some of the ways in which the National Bureau of Standards supports industry and commerce in the United States.

As part of its role in supporting the national measurement system, the Bureau has the primary responsibility for ensuring that measurement standards are available for public and industrial use. We do this by providing calibration services, measurement assurance programs, standard reference materials, evaluated data, a wide variety of publications, and a selection of training programs. But since we clearly can't deal directly with the hundreds of laboratories in the country, we tend to work through intermediate standards laboratories, providing them with transfer standards and services, which they in turn use to provide services to other laboratories and field workers. Besides providing services to large numbers of users, such intermediate-level laboratories have the advantage of being closer to the users and of providing faster service. With intermediate-level laboratories, the programs can be adapted to the needs of the region, and the training of field personnel is often more convenient. 
Intermediate standards laboratories take several forms. Some are run by State and local governments. In our country, the States have responsibility for regulating the use of weights and measures in commerce. It is up to State and local officials to see that equity prevails in the marketplace. This is quite different from your system. I understand that in Egypt the Administration of Assay and Weights, under the directorship of my friend Mr. Saad Zaghloul Ahmed, has responsibility for regulating the weights and measures throughout the country. In the United States, there is no enforcement at the National level, but the National Bureau of Standards does have the responsibility for providing the States with the calibration services necessary to ensure that they have accurate values for their basic reference standards of mass, length, and capacity.

Another type of intermediate standards laboratory is that run by industry for the purpose of controlling the quality of its products. Quality in manufacturing is defined as the measure of how closely a product conforms to specifications. Thus quality depends critically on the accuracy of the available standards and the measurement methods used to compare the products against these standards.

NBS also supports industry through its participation in trade associations and voluntary standards writing committees. Thirty percent of our professional staff are members of standards writing committees such as the American Society for Testing and Materials. In addition, NBS works closely with the National Conference of Standards Laboratories, which has about six hundred members, and the Council for Optical Radiation Measurements with about one hundred and fifty members. We find that this is an effective way to disseminate the results of our research and to keep ourselves informed of industries' requirements for quality control.

There are two basic approaches to quality control. The first--and more traditional--approach is to inspect the actual product, comparing it with an ideal model. If it conforms within certain tolerances, it is accepted; if not, it is rejected. Each individual product may be inspected or, to reduce the cost, a statistical sample may be taken. Sampling is of course essential when inspection entails destroying the product.

The second approach is to monitor the production process itself. This approach is familiar in the chemical process industry, but is new to many other industries. It is based on the premise that a process cannot change from making a good product to making a bad product without first changing some process parameters. Hence, by monitoring the state-of-process and preventing change in that process, bad products can be avoided. This approach to quality control may be realized by periodically calibrating production machinery off-line or by on-line, real-time monitoring of process parameters.

This second approach has the advantage that it overcomes any apparent conflict between quality and productivity. Scrapping or reworking finished products to guarantee quality necessarily reduces the quantity available for sale. "Making it right the first time" through process control can greatly reduce the cost of inspection and rejection. This is the approach that Japan has adopted so successfully. 
The Bureau offers many services in support of quality control. Industry is free to participate in any or all of them. We have no enforcement or direct regulatory function, so industry does not view us as an adversary. We take great pride in our objective neutrality on technical questions, and I think this is a large factor in our effectiveness.

The services that NBS provides to support industry can be divided into three broad categories: measurements NBS makes, information we provide, and joint programs with industry partners. Let me briefly describe the kinds of services within each of these categories. You will hear more details about some of these services from other speakers.

NBS provides calibration services for several hundred different measuring devices. We do this by comparing the customer's instrument against a primary standard which we maintain. We perform about 7,000 calibrations each year for about 1000 customers. The customer is charged a fee which covers our direct costs of providing the service. We currently calibrate instruments for measuring things such as mass and dimensions, mechanics and acoustics, time and frequency, electrical quantities, optical and ionizing radiation, and thermodynamic quantities.

The accuracy to which the Bureau calibrates an instrument is determined both by the accuracy required at the point of use and by the number of links in the calibration chain. To illustrate this, we can take an example from the field of radiation therapy. It is generally agreed that if we are to control a tumor without unnecessarily damaging healthy tissue, we must know the amount of radiation actually reaching the tumor to an accuracy of five percent. But because the patient may move and because we don't know the exact position of the tumor, we must be able to measure the dose that we administer to an accuracy of three percent. An accuracy of three percent in the hospital requires an accuracy of two percent at the intermediate level and an accuracy of one percent for the Bureau's national standard.

The second set of measurements NBS makes is on standard reference materials. These may be well-characterized, homogeneous materials certified for chemical composition and physical properties, or they may be simple artifacts certified for specific properties. They are used primarily to calibrate instruments, to validate methods and experimental data. We currently offer about 900 such materials and sell about 40,000 units each year.

About 100 of these standard reference materials help maintain the basic measurement quantities, such as temperature, upon which all other measurements ultimately rest. For example, standard reference materials are used to establish reference points on the International Temperature Scale, the scale to which all temperature measurements are referred. As a result of a 20 year cooperative effort with a worldwide network of laboratories, standard reference materials have recently contributed to improvements in the compatibility of thermal conductivity and expansion measurements important in energy conservation efforts.

About 700 standard reference materials are currently used by industry to establish and maintain measurement quality control in the processing and manufacturing of finished goods. 
Some reference materials apply particularly to measurements in agriculture and food science. The reliable determination of constituents in agricultural products, foods, and beverages is necessary to evaluate the role of nutrients in health and disease, and to establish dietary requirements for these nutrients. Such measurements are also used to establish normal concentrations of nutrients and to investigate the effect of packaging and processing foods by different methods.

A healthy scientific environment is essential to the technological advances needed in a modern economy. Publication of the results of NBS research in the scientific literature makes an important contribution to the science base underlying the electronics, manufacturing, chemicals, materials, instrumentation industries. To provide the scientific and engineering community with reliable sources of data, NBS develops data bases of evaluated physical and chemical properties of substances. We collaborate with other organizations to maintain twenty-five permanent national data centers.

The alloy phase diagram data program provides a good illustration of the way industry uses this information. Phase diagrams are graphs that show when a mixture of two or more metals or other substances will melt or separate into components. They help to relate the properties of the alloy to composition and temperature. Phase diagrams are the "road maps" that allow metals producers to design and process new alloys with improved properties or lower costs. In this NBS program, phase diagrams are evaluated by experts throughout the world. NBS coordinates the program and has overall technical responsibility for the quality of the data, and we produce some key data in our own laboratories. The metals industry through the American Society for Metals provides for the dissemination of this data through computerized data bases available to the industry users.

Standards play a critical role in trade and industrial quality control. They can ensure for equity between a buyer and seller and serve as the basis against which actual performance is measured in determining quality. In contrast with most other industrial nations, the United States uses a voluntary process to establish engineering or product standards. These standards are the published documents that represent an agreement among interested parties to a set of requirements that must be met by a material, product, or process. NBS maintains a world-wide comprehensive reference collection of engineering and related standards. The collection includes more than 240,000 standards, test methods, codes, and recommended practices issued by voluntary standards groups and foreign national and international standards organizations. NBS does not set these standards but our people participate in voluntary standards groups, notably ASTM. Mr. Goodemote will describe this system in more detail.

Finally, we have a number of ways in which we work directly with industry to support its measurement needs.

In our measurement assurance programs, we work directly with the industrial and other laboratories to improve their ability to make accurate measurements. These programs go one step further than the calibration service in that they allow the customer to document the accuracy of his entire measurement system including the performance of the instrument and personne1, and the adequacy of the procedures. For this reason it is much 
more desirable than instrument calibration, which does not by itself assure correct measurements.

Another way we work directly with industry is through our Voluntary Laboratory Accreditation Program. This program provides national recognition of competent testing laboratories. We test the ability of a private laboratory to make specific kinds of tests by providing samples, collecting their data, and statistically analyzing results against controls. If the results are satisfactory, NBS then accredits the laboratory as competent to perform that test.

NBS tries to serve as a focal point for science and technology by actively promoting conferences and symposia. About fifteen thousand individuals attend conferences at NBS each year and about sixty percent are from private industry. These meetings provide a forum for industry attendees to exchange ideas among themselves and with government and academic scientists to keep pace with the latest advances in a wide range of science and technology areas.

We open up our laboratories and measurement facilities to industrial scientists through informal collaboration and through a Research Associates Program. This program allows scientists and engineers from industrial, professional, or trade organizations to work at NBS for specified periods of time under sponsorship of their employer. They work on nonproprietary projects of mutual interest to the sponsor and NBS. We currently have over one hundred research associates working at NBS. This program has proved to be one of the most effective means of transferring measurement technology rapidly into private industry. It also allows industry access to many of NBS' unique facilities, such as our research nuclear reactor, that would be impossible for industry to duplicate.

In summary, NBS plays two key roles in the U.S. economy. First, we provide the national system of measurements and maintain its link with international standards. Second, we support commerce and industry by providing a wide range of measurement and research services. NBS has a long tradition of effective cooperation with industry. This cooperation is vital to continued economic growth and general public benefit. 


\author{
Building Technology - From Research to Practice \\ Charles G. Culver \\ Chief, Structures Division \\ National Bureau of Standards \\ Washington, DC 20234
}

This paper describes the role of research in developing improved building performance. Activities involved in the construction process and the role of standards are included. Research in concrete technology underway in the Center for Building Technology at the National Bureau of Standards contributing to improved standards and building practices is discussed.

\title{
1. Introduction
}

Buildings and other structures represent a substantial portion of a nation's wealth. They support a variety of activities ranging from providing basic shelter to facilities housing commercial and industrial functions. Safety and economy are two important factors that must be considered in the design and construction of buildings. Design standards and quality control provide a means to achieve these. This paper will examine the role standards play in the construction process and the development of improved standards through research on building performance.

To understand the importance of standards we need to first examine the bullding process, both the activities involved and the various participants. For each building or construction project we can break the life cycle of the activities into the following phases: (1) programming, (2) preliminary design, (3) detalled design, (4) site construction, (5) occupancy, and (6) removal or renovation. In the programing phase the owner works with the design team, the financier and regulatory authorities at the local or national level to define the requirements the buildings should meet for its intended use. Applicable zoning and overall safety requirements are defined at this stage.

During the preliminary design phase the design team works with potential contractors; fabricators and materials suppliers to identify the configuration for the building and the types of structural, foundation and other systems to be used to meet the requirements of the program. Various alternatives are evaluated in this stage and trade-offs are made based on economic, functional and practical considerations. The detailed design phase follows with the development of plans and specifications for the facility.

During site construction the contractor, including the general contractor and many specialty contractors for areas such as structural framing, excavation, cladding, roofing, etc., work with oversight from regulatory authorities and designers to produce a bullding meeting the plans and specifications.

The occupancy phase in which the bullding serves its intended purpose involves the owner, users and maintenance organizations. At some point in the iffe cycle of the building it will be necessary to either renovate the building to accommodate different uses, to repair it to extend its useful life or demolish it. At this point the owner, designers, material suppliers contractors and regulators repeat the process. 
NBS technical activities in building technology include research, technical problem solving, development of technical data, technical policy assistance to decision makers in Federal, State and local government and participation in the work of standards developing organizations. The activities are conducted in cooperation with industry, professional organizations, standards organizations, model building code organizations, university researchers, the National Academies of Sclence and Engineering, other Federal agencies, and many other groups. NBS participates in international organizations concerned with bullding research to assure that research efforts are coordinated and that the world's knowledge base is avallable for the improvement of U.S. bu1lding practices. These activities provide the new knowledge required for response to national needs in the development of improved bullding practices and their implementation in the building community.

The results of NBS work are used in decision making throughout the entire building process. Owners and designers use NBS technology to define the qualities desired in a building. Designers and regulators apply specifications derived from NBS performance criteria in determining the qualities of the building. Designers, regulators, and testing laboratories employ measurement technology developed by NBS in assessing the compliance of the building with the design specifications. Owners, occupants, users, developers, contractors, labor, financiers, and manufacturers look to NBS performance criterla and the supporting measurement technology for assurance of bullding qualities consistent with secure investments and the safety, health and welfare of the occupants and users.

NBS does not promulgate or set building codes, standards, specifications or measurement, test and evaluation methods. It provides an objective source of technical information for national consensus standards organizations such as the American National Standards Institute; the American Soclety for Testing and Materials; the American Society of Civil Engineers, etc. Close cooperative work with the National Conference of States on Bullding Codes and Standards, the model code organizations of bullding officials, and the National Institute of Building Sclences, leads to standard practices that meet the needs of the regulatory authorities of State and local governments. Research providing the knowledge for these standard practices is conducted in cooperation with university and industry research laboratories.

Current research in concrete technology conducted in the Center for Bu1lding Technology at NBS will serve as an example of the way we contribute to developing improved standards. The work on concrete includes: research on strength gain characterization, fracture characteristics of mortars, test method development, nondestructive evaluation approaches to quality control, developing design criteria for improved safety of concrete construction, earthquake resistance of masonry, and corrosion resistance of steel reinforcing.

The work on strength gain characterization of concrete involves the early stages after hardening. Basic research on cement is underway to improve understanding of the physics and chemistry of cementing reactions. This research will provide a basis for computer-based predictions of the performance of cement and concrete in actual use. For example, working with a visiting scholar from Bucknell University, NBS researchers have developed a preliminary mathematical model for the hydration of tricalcium silicate (the major constituent of portland cements) and are testing 1t against data obtalned with a very precise multiple microcalorimeter built at NBS and a system for automatic analysis of the aqueous phase. Knowing the particle size of tricalcium silicate and the water-to-tricalcium silicate ratio, the following variables can be obtained from the model as a function of time: (1) degree of hydration and hydration rate; (2) amounts of calcium hydroxide and calcium silicate hydrate gel formed; (3) intergranular porosity; and (4) amount of free and combined water.

Following on the studies of tricalcium silicates, more complex systems consisting of mixtures of portland cement compounds (such as $\mathrm{C}_{3} \mathrm{~A}$ and gypsum) are being studied using the same approach-developing conceptual and mathematical models and testing them against laboratory data. The NBS research plan is to study other variables that affect hydration and microstructure development, including the exact nature of the cement compounds, water-to-solid ratio, solutes in the mixing water, nucleating agents, temperature disturbances such as temperature changes, and dilution. Models will be developed to use for predicting the performance and strength of cement pastes based on composition. The preliminary tricalcium silicate hydration model recently has been complemented by a new NBS model which deals with microstructural changes in the calcium silicate hydrate. 
Studies are also being conducted of the fracture characteristics of mortars. It involves the relationships between the microstructure of mortars and their microcrack characteristics. New models will be developed to explain cracking based on factors like porosity, the constituents of mortar, and moisture content. Previous studies of the fracture mechanics of plain and polymerimpregnated mortars performed at NBS showed that mortar processing variables--such as water-to-cement ratio and curing time--had no significant effect on fracture mechanisms of the impregnated mortars. The effect of impregnation of the mortars with polymers was to hinder the onset of microcracking and lead to greater fracture stress. We have also investigated the influence of maximum pore size and cement-aggregate bond on the fracture of mortars. This work has shown that, for the normal range of maximum pore sizes, the fracture is sensitive to the aggregate-cement bond as well as to the maximum pore size. This basic technical work is intended as a foundation for the development of improved laboratory test methods and nondestructive field test methods for assessing the quality of concretes and other cement-based materials.

NBS research on cements and concrete is complemented by the NBS-managed activities of the ASTM-sponsored Cement and Concrete Reference Laboratory (CCRL) and the AASHTO Materials Reference Laboratory (AMRL), which carry out inspections of testing laboratories and distribute proficiency test samples. Established at the Bureau in 1929, the Cement and Concrete Reference Laboratory sends inspectors to 290 cement testing laboratories and 350 concrete testing laboratories which request the service every two years. Under the CCRL Proficiency Sample Program, participating laboratories periodically receive two samples of a given type of material from different sources or lots. The laboratorles perform specified standard tests on the samples and report the results to CCRL. CCRL provides confidential reports to the individual laboratories, comparing their test data with that from other laboratories. This gives cement and concrete laboratorles throughout North America a uniform way of checking the quality of their testing.

Laboratory tests can assure the quality of materlals delfvered to the site, but there is also a need for proper on-site evaluation of the quality and unfformity of hardened concrete and reinforcement. Standard test methods are avallable for assessing the characteristics of plastic concrete prior to placement. However, the quality and uniformity of hardened concrete are also affected by construction practices, workmanship, and curing conditions. Concrete inspectors are responsible for determining whether the building contractor is adhering to acceptable practices and design specifications, but inspectors generally form only subjective conclusions that depend on their level of training and experience. NBS research has evaluated nondestructive evaluation approaches to the quality control testing of hardened concrete. The development of criteria for selecting NDE procedures is part of a larger project supporting improvement of construction safety standards. Several projects are underway to provide design criteria and test evaluation methods to improve American National Standards Institute (ANSI) and OSHA safety standards. These include development of probabilistic models for construction loads and determination of load factors for design of falsework; development of an analytic model to predict construction load effects on structures during construction; development of criteria for formwork removal based on an analytical model of construction load distribution; development of standard test methods for performance evaluation of scaffolding systems; and NDE selection criteria.

Working under the National Earthquake Hazards Reduction Program, CBT is also conducting research on the response of both reinforced and unreinforced masonry to selsmic conditions. Wall specimens measuring 4 by 6 feet $(1.2$ by $1.8 \mathrm{~m}$ ) with a thickness of 8 inches ( $200 \mathrm{~mm}$ ) are subjected to a combination of compression and lateral loads. The wall sections incorporate several types of spacings of steel reinforcement. Results of the research will be shared with the Building Seismic Safety Council representing private industry, and the Interagency Committee on Seismic Safety, representing Federal agencies, in construction to aid development of improved industry consensus standards and uniform Federal design regulations.

Proper design, construction, and inspection procedures can safeguard a concrete structure from collapse, but premature decay froin corrosion remains a substantial threat. Many of the bridges built in the 1950's, particularly those of the interstate system and those crossing large rivers in major northeastern cities, have deteriorated years earlier than expected because of the corrosion of reinforcing steel in concrete bridge decks caused by deicing salts. It is estimated that corrosion of steel in concrete bridge decks contaminated by chloride costs the U.S. economy more than $\$ 200$ million annually. 
Federal and state highway departments are now using protective coatings for the reinforcing bars in many areas but only time will tell whether the new materials will prove much more durable than the old. NBS conducted the ploneering research on coatings for steel reinforcing bars, developing the performance criteria and testing procedures that became ASTM standards. Subsequently, epoxy-coated rebars have become commercially available and a new industry has developed.

NBS researchers are working cooperatively with Spanish scientists on one of the most comprehensive studies to date of the corrosion of pre-stressing steel. NBS is preparing a report on the principal factors affecting corrosion rates, including oxygen, chloride lons, hydrogen lon concentration, and stressing conditions. The Spanish researchers are studying the effects of metallurgical factors on corrosion. Among previous NBS work on tests related to concrete durability has been the development of a method for studying the effects of $\mathrm{pH}$ and concentration of sulfate colutions on the sulfate resistance of immersed mortar bars. This method is now being evaluated as a possible standard test by a committee of RILEM (the International Union of Materials and Structures Research and Testing Laboratories).

Research is also underway to develop general probability-based approaches to predicting the service life of concretes and coatings for steel, as well as other construction materials such as roofing and adhesives. The research 1s establishing durability tests and mathematical models to predict service life as a function of service conditions. The work will help strengthen the existing ASTM Standard Practice E632 for development of accelerated tests for service-11fe prediction, which was based on NBS work.

Investigations related to specialized applications of concrete are also carried out. Work has been done on the impact resistance of several types of reinforced concrete, to provide information needed by the nuclear, defense, and security industries in constructing secure areas. Preliminary results from repeated impact tests indicate that steel fibers, in comparison with expanded metal and conventional steel bar reinforcing, can substantially increase the impact resistance of concrete. Ultrasonic pulse velocity measurements appear to be useful in assessing the crack damage occurring during the repeated impact test.

The basic research on concrete at NBS can help prevent the fallure of concrete structures. By learning more about how concrete performs and why it falls, NBS research is helping to make concrete more predictable and concrete structures more reliable.

\section{Role of Standards}

Building codes are legal requirements imposed by the authority with jurisdiction over the facility to provide for public health, safety and welfare. Building codes speak to levels of performance required such as the wind loading a building should resist, the extreme temperatures for which the heating or cooling system should be able to maintain selected internal temperatures, or the load carrying capacity to be provided by structural members. Sometimes, prescriptive codes state the actual materials and proportions the building must have in order to achieve such performance qualities. Usually, bullding codes incorporate building standards in order to describe the qualities required.

Building standards are an integral part of building codes. They deal with technical requirements for achieving the desired level of performance. They lack the legal or regulatory impact of codes. Building standards fall into two classes, industry standards and consensus standards. Industry standards will be developed and accepted by a particular industry. An example in the United States is the specification for the design, fabrication and erection of structural steel for buildings developed by the American Institute of Steel Construction, an organization representing the steel industry. A consensus standard will be developed and accepted by a group representing a broader interest including industry, the professions using the standard and the consumers affected by the process or product standardization.

Building standards provide an effective means for achieving improved bullding performance. This is accomplished through research and incorporation of the research results in such standards. Research and development for the products and equipment used in the building process is essentially 
the responsibility of industry. Manufacturers of materials and equipment profit from this research when they bring a better product to the marketplace. Other research and development provides more generic knowledge including characterization of the environments in which buildings must function (such as wind loads to be anticipated during the service life), characterization and definition of the performance qualities of bulldings, components and systems and methods of testing for these performance qualities. Universities and government research organizations play an important role in this generic research. The following section presents an example of the use of research results in the development of improved standards.

\section{Improved Standards}

The American National Standard A58 Minimum Design Loads for Buildings and Other Structures is the only U.S. national voluntary consensus standard that deals with structural loads. The new version of the standard issued in 1982 incorporates many research findings from research programs conducted at the Center for Bullding Technology.

Developing loading requirements for the design of bulldings has been a major thrust of the Center in recent years. The work includes wind loads, snow loads, earthquake loads and live loads. This research involved the development of instrumentation and experimental techniques for both field and laboratory wind load/response measurements in model and full scale, the measurement and characterization of load spectra and extreme-value distributions used to establish load criteria for serviceability and ultimate limit states, the development of mathematical models for response prediction which incorporate nonlinear stiffness and damping parameters and which allow for the variation of loads in both time and space, and the application of reliability theory in developing the serviceability and safety criterla. The work was carried out in cooperation with academic and professional groups.

The new standard was developed by a Committee representing the numerous interests in building construction: consulting engineers and architects, professional and trade associations, researchers, code officials, and the Federal bullding community. Center staff served as the Secretarlat to the A58 Committee and were responsible for managing and coordinating the revisions. The new standard, for the first time, enables consistent safety levels to be specified for the principal construction technologies. The live load provisions contain a new load reduction procedure which draws upon survey data gathered and analyzed as part of NBS research on structural loads. Revisions to the A58 wind speed map, gust factors that account for turbulence, and wind pressure coefficlents for low-rise bulldings were based on experimental measurements by NBS on full-scale structures. Several features of the new earthquake provisions are taken from model seismic regulations for buildings that were developed in a collaborative program between the Center for Bullding Technology, the National Sclence Foundation and design professionals from throughout the United States. An expanded commentary on general structural integrity reflects CBT efforts to model the occurrence of accidental loads and to develop provisions to prevent progressive collapse.

\section{Conclusion}

Bullding standards incorporating technical provisions are an effective means for improving building performance. Bullding research is needed to develop technical information to serve as a basis for these standards. These standards should be developed by professionals involved in the design process, researchers, code officials, industry representatives and others in the bullding community. 



\title{
Private Industry's View of Standards and Certification
}

\author{
Richard Goodemote \\ Chairman of the Board \\ American Society for Testing and Materials \\ Philadelphia, Pennsylvania
}

\section{Standards, an Economic Necessity}

Standards have been essential components in the development of world commerce. They were the cause, not the result, of the Industrial Revolution. Today they are a basic economic necessity. Private industry, as we know it, could not exist without a very extensive standards system.

For example, manufacturers of consumer goods typically purchase well over half the cost of their product from other manufacturers who produce standard components and materials. The automobile manufacturer does not produce his tires or wheels, light bulbs, wiring, generator, brake linings, bearing, fasteners, windows, or most other components or materials. All these parts are available from suppliers who are in turn much involved with their standardization.

Standards reduce very significantly the engineering man hours required to design products. Standard components need not be redesigned and detailed; they are specified by name or number and are less expensive than non standard parts. The repair and servicing of products is likewise made more economical when standard parts are used.

Standardization in the service industry is no less important. Without world standards for fuel and lubricants there would not be a modern transportation industry. The certification and purchase of goods and services depends upon standards.

Private industry is heavily involved in the standardization process because it is a fundamental part of their business.

In total, standards development is an enormous activity. It draws on the knowledge and participation of hundreds of thousands of people throughout the world, many of whom are the leaders of thought in their respective field of interest or profession. The International Standards Organization has 5000 standards and there are many thousands of standards prepared by private organizations that have become world standards. All these and the many more that are national or industrial standards are readily available to those who wish to use them. 
Standards are produced by professional societies, governments, industries, private companies, and standards organizations. Private industry is inclined to $j$ udge standards' producers on their historical record for producing useful and beneficial standards and by the degree of consensus that is a part of their standards writing process. For many years the trend has been toward a broader participation in the development of standards. Today, it is not unusual to find purchasers, users, representatives from government, the academic community and industry, all participating in the development of a full consensus standard. Indeed, the "Standards Code" of the International Agreement on Technical Barriers to Trade, of which thirty-six countries (including the United States and Egypt) are signatories, requires that foreign countries be made aware of new standard developments that might have an influence on their export business.

The benefit of all this consensus is more widely accepted standards. The price is time. The full consensus standards writing process is inherently time consuming. The challenge to private industry and to all participants is to hasten the process without compromising the system that requires all interested parties be heard and their thoughts considered.

\section{Standards and Innovation}

A second reason for private industry's significant investment in the standards writing industry is less altruistic. It relates to the special business interests of industries or even individual manufacturers. It is an altogether honest endeavor in a free and competitive society, and relates directly to the problems faced when new or old standards influence the producers' plans for innovations in their products or services.

For example, when plastics were first introduced for use in plumbing equipment, there were many standards, some written into government regulations, that unfairly restricted their use. It was therefore necessary that those supporting the development of plastic plumbing equipment convince appropriate members of the standard community that changes in the existing standards are needed. A similar situation existed in the electrical equipment industry.

In both cases the existing standards contained certain design requirements that specified materials to be used that were not plastic. There were requirements for metal sheathing for electrical cable, for example; or copper and galvanized iron for water pipe. 
Implicit in this discussion of product innovation is the second maj or reason private industry contributes time and expertise to the standardization process. It is to prevent the development of standards or to correct standards that prejudice the design of a product or service in such a manner that the producer's or user's choice is unnecessarily restricted.

III. Government and Industry Cooperation

Governments have the responsibility for the common welfare, international agreements, and the metrology concerned with the nation's weights and measures. All these activities influence standards development. Government standards become codes or regulations that are written into the law of the land, and tend to be unchanged for long periods of time. Governments also are maj or purchasers, purveyors of services, and builders. In these endeavors their standards are often the same as those of the private sector, and should be reviewed and updated on a regular basis.

In many of these standards activities government needs the expertise available in private industry. And, as we have seen, private industry must have their government's appreciation of the effect that codes and regulations have upon the innovation process. For these and other reasons, it is the rule today that governments and the standards organizations in their private sector have cooperative working relationships. This is a practical necessity. Totally new products and services, however, are relatively rare. Most product developments evolve by changing existing products, a step at a time. This is also a process that can cause intense standards activity.

Consider that the important attributes of a product are usually not independent variables, to be changed by themselves without affecting each other. Rather they tend to vary inversely with one another. For example, for a given tire design, traction tends to vary inversely with tire wear; so the tire industry tries to develop tires with acceptable traction (a standard) that will wear longer. In garment design comfort tends to vary inversely with durability (a standard) so the synthetic fiber producers hope to develop fibers with high durability that are as comfortable as cotton or wool. Large aircraft are efficient but require engines so powerful that noise level (a standard) is unacceptably high; so the high bypass engine is developed to solve the noise problem but not restrict the size of the craft. These examples are meant to illustrate the influence standards may have on the innovation process. They are over simplified only in that many more than two attributes are involved in developing a new product or service. As one attribute is changed several others are affected. 
To protect their interests private industry brings technical expertise to the standardization process. However, it should not be expected that this expertise is unbiased. Each producer will attempt to prevent a standard from having a negative effect upon his product. This is a reason for balancing the standards committee in such a way that no single interest group dominates.

\section{Certification}

Private industry is much involved with certification systems. In turn certification systems are dependent upon standards to define precisely what is to be certified.

For the producer, there are three exposures to certification. First, the producer's vendors are asked to certify their parts, materials, and services. Second, governments require certifications that specific standards have been met. Third, purchasers ask producers to guarantee or certify their products and services.

For the most part, certification systems around the world are not so well disciplined as are standardization procedures. Even the definitions of terms are not widely standardized; although there is much careful thought being applied to the general subject at this time. Notably, the Iso has been much involved, and with considerable international expertise, in developing standards for certification systems.

Even without widely accepted definitions and procedures, there are certification systems that private industry has used very effectively for years. A prime example of an old, and internationally accepted system is the American Society for Mechanical Engineers Boller Code. As Indicated above, the terms are confusing, because the ASME calls the code on accreditation. In fact, the ASME procedure accredits the system that designs, builds, installs and monitors the boiler and controls. It is not the individual boiler that is approved.

There are product certification systems that follow the same procedure. Once again, the terms are confusing. The "certification mark" on a product or service does not always mean what it implies. Most certification marks indicate an approval of a characteristic of the product design, such as safety, that has been examlned by the producer or a third party. Because terms, definitions, systems and marks are not standardized the user is well advised to determine precisely what a certification system guarantees.

A very effective certification system has been used for many years by quality assurance people to minimize the receiving inspection of parts and materials required on the part of the user or manufacturer. The certification agreement requires the vendor to specify the quality level of his part, usually in statistical terms, based upon an agreed upon specification and inspection system. The vendor also agrees to reimburse the manufacturer or user for expenses incurred if the particular parts do not conform to the certified quality level. 
This well established system works because it has all the necessary parts. There is an agreed upon specification or standard; an agreement on the quality assurance system for monitoring and reporting variations from the standard; and an agreement on the part of the certifier to assume full responsibility for the cost of his mistake.

Purchasers of large quantitles of goods and services not controlled by government regulation face the problem of establishing certification systems that work. Generally, the risk the purchaser takes will vary inversely with his technical know how. If the purchaser lacks the technical know how to protect himself, he can hire a quality assurance consultant or private laboratory with engineering analysis capabilities and quality control know how. There are a large number of private laboratories offering testing and certification on an international basis. Some have been established to help with the large number of certification requirements around the world, many of which are requirements of regional rather than national governments.

As in the case of standards, the International Agreement on Technical Barriers to Trade asks that all signatorles be allowed equal access to each others certification programs.

\section{The American Society for Testing and Materials}

There are a great many organizations around the world that write voluntary standards. The term voluntary standard is used to identify a standard that is developed and used voluntarily until or unless a goverment includes the standard in a regulation. These voluntary standard organizations differ in the degree of openness or consensus used in the development of their standards.

For example, company standards have a narrow consensus of those within the company that produce them, but can be very important. For example, in the United States the General Motors Corporation develops engineering standards, material processing standards, and drafting standards for their own use. Coples of these standards are made avallable to other companies and thousands take advantage of them to make significant savings in their engineering man hours.

From a consensus viewpoint, the American Soclety for Testing and Materials represents the opposite extreme. It is a full consensus standards writing organization; which means all interested parties may participate in its activities. The name of the society is old; it no longer reflects the total activities of the society; so ASTM, the abbreviation, is used. 
ASTM is an organization that maintains and administers a rigorous set of rules which must be followed in the development of an ASTM standard. The rules of the soclety are generic and are applied to all types of standards: materials, test procedures, products, definitions, specifications, et cetera. But, ASTM does not establish the need for a standard.

The need is first established by a group apart from ASTM. This may be a government, industry, consumer, professional group or a combination of the above.

The ASTM procedural rules for committees that write standards are are extensive and detailed. In broad terms, however, consensus is achieved by two sets of rules.

First, ASTM standards committees are balanced between producers or sellers and users or others who have an interest in the product, material, or service that will be influenced by the standard. Producers can not dominate the committee. They are matched in number by non producers; and a producer can not be chairman of the committee.

Secondly, at each step in the standards development process, committee members are balloted. Every negative ballot must be recorded and considered individually, and committee members can challenge or appeal to a "higher court" any action they believe violates the society rules.

ASTM maintains the integrity of the system that produces the standard. The output of the system is judged by the usefulness of the standards and the system is modified or corrected accordingly.

ASTM standards are producers with a concern for their use throughout the world. Each year there is greater participation by ASTM members from countries outside the United States. The symposia and publications of technical information related to standards is also of growing international interest.

For example, the Egyptian Academy of Sclentific Research and Technology, Alexandria University, and the ASTM committee on Waste Disposal are presently planning an international symposium on Industrial and Hazardous Waste, to be held in Alexandria in June 1985. The subject matter is clearly an example of international interest and should be an area for international cooperation in standards development. 
The Role of National Standards Bodies
in Standards and Trade

\author{
John L. Donaldson \\ Deputy Director \\ Office of Product Standards Policy \\ National Bureau of Standards \\ Washington, DC
}

\title{
Introduction
}

In most countries, a single, central organization coordinates the development and use of national industrial standards. In the United States, the American National Standards Institute is sponsored by private industry as its "national standards body" (NSB), and it coordinates the national standards activities of more than 200 private standards-writing organizations. In Egypt, the Egyptian Organization for Standardization (EOS) is responsible as the NSB for the

development of national standards. Besides its domestic responsibilities, the NSB also has a significant international role; together these place considerable demands on NSB staff competence and facilities. For the NSB in an industrializing country the challenge is great: international and domestic demands strain the limited technical and financial resources available. By taking advantage of opportunities for technical assistance offered by international organizations and the NSBS of highly industrialized countries, however, the industrializing country's NSB can better utilize its limited resources and more effectively contribute to its country's development.

\section{National Standards Bodies}

Each NSB has three important functions: it represents its nation in international standardization activities, it aids in domestic industrial development, and it enhances consumer welfare in its country.

These functions require that the NSB conduct a variety of activities. To protect its nation's interests, the NSB assures knowledgeable participation in the development of international standards and systems for their application. To aid domestic development, the NSB provides the standards needed by industry by establishing the framework for their development when they do not al ready exist or by adapting external standards to the domestic environment. The NSB also fosters the development of the metrological foundation for accurate standards application. To enhance consumer welfare, the NSB provides sound methods and standards for industrial quality control and sees that there is a system for assuring that products conform to health, safety, and environmental standards, including especially imported goods. 
The conduct of these diverse standardization activities presents a considerable challenge to the NSB in an industrializing country. Many technical competencies are needed to represent the country in international standards activities, and these are generally in short supply. Existing domestic standards are usually limited in number and the resources required to produce the standards that must accompany industrial development are apt to strain the capacity of the NSB. The variety of tests, measurements, and equipment fundamental to assessing the acceptability of goods produced for the marketplace imposes additional resource burdens on the industrializing country's NSB.

These are the problems that face all NSBs in industrializing countries as they fulfill their responsibilities. They are real, but they are not insurmountable, as will be discussed later. First, though, there follows a review of some of the activities in which the NSB engages.

\section{International Standardization}

The scope of international standardization is extensive and requirements for participation are technically diverse. A recent survey by the U.S. National Bureau of Standards reveals 272 international and regional organizations currently involved in standards and related activities. 1 Organizations range from "A" to "Z": from the AACC--The Airport Associations Coordinating Council-- to the ZDA--The Zinc Development Association. While many of the organizations consist of representatives from fewer than 10 countries, there are over 150 different countries involved overall.

The International Organization for Standardization (ISO) is the most productive of these international organizations, being responsible for about 5000 of the more than 7600 international standards. In the past ten years, ISO has introduced an average of 300 new standards each year and has revised existing standards at a rate of approximately 70 per year. The work 1 oad was carried by more than 2000 technical bodies in 1982: 163 technical committees, 612 subcommittees, and 1331 working groups. 2

Egypt's representative to ISO, the EOS, is involved in 96 technical committees, participating on 26 and observing on 70 others. The 13 most active ISO members, which are among the most industrialized countries of the world, participate or observe in 155 or more committees. Four of these countries are involved in all ISO committees. To increase EOS' involvement to the level of the highly industrialized nations--and thereby derive similar benefits--will require case-by-case evaluations as a bas is for considerably increasing EOS' technical commitment.

TNational Bureau of Standards Special Publication 649, "Directory of International and Regional Organizations Conducting Standards-Related Activities," April 1983.

2ISO, Memento 1983. 
Industrial nations develop and depend on large numbers of standards. The growth in a nation's standards base accompanies its industrial growth. The number of standards maintained by NSBs in the most industrially active nations ranges from about 5000 -- Canada and Sweden, for example -- to 23,000 (USSR) and 35,000 (Germany); the United Kingdom has 8000, and France 11,000. The United States has about 28,000 industry standards. EOS already had about 1500 standards in 1980 and was adding new ones at the rate of 50 to 60 a year. Anticipated Egyptian industrial growth requires an increase in EOS' cap acity to provide domestic standards.

Once standards have been established, mechanisms are required to assure their use. Product testing and certification systems for assuring claims of product conformance to standards should incorporate production quality control requirements, inspection, and testing. Approaches differ among countries: some systems are nationally operated and others are operated below the national level or by private bodies. In Egypt, the EOS Quality Control Center has been assigned this function. In some countries, the NSB is not involved in its nation's certification system. A 1983 survey of the 58 members of the ISO's Information Committee produced 29 responses concerning certification systems. 3 Twenty-eight of the 29 indicated the existence of certification systems in the member's country: 6 indicated a national system, 8 indicated "other" systems in the absence of a national system, while 14 indicated that both were present. In the United States, there are both public and private certification and testing programs. Among the more than 60 private sector certification programs, Underwriters' Laboratories (UL) is the largest, with an annual operating budget of nearly $\$ 100$ million. Widely recognized certification programs are operated by NSBS in the United Kingdom, France, and Germany. These three programs and UL together account for over 200 years of operation! It requires a sustained commitment to long term development and consistently successful operation to realize such a respected national system.

Development Assistance

The biggest challenge faced by every NSB, and by EOS, is to satisfy increasing demands with sharply limited technical and financial resources. For an industrializing country, these demands can be more effectively addressed by taking advantage of opportunities afforded by international organizations and by the NSBs of more industrialized countries. EOS can more successfully handle its difficult role by seeking out these opportunities. For example, ISO's Development Committee (DEVCO) provides a for um for exchanges between industrial and industrializing nations $0^{s:}$ the world on matters concerning standardization. Thirty-seven ISO members participate in DEVCO's activities and 15 others are observers; EOS is a participant. EOS' director, Dr. Fouad Sobhy, has been Egypt's representative and can speak on the benefits derived from DEVCO's undertakings.

${ }^{3}$ Report to XVth Meeting of INFCO, "Survey Regarding Information on Certification Systems" ISO, September 25, 1983. 
DEVCO conducts a variety of activities:

(i) preparation of development manuals,

(ii) training of staff personnel,

(iii) study tours for officials,

(iv) sponsored participation in ISO technical meetings, and

(v) development of standards to meet special needs.

These activities are conducted by ISO members with considerable experience in standardization for members whose national standards bodies have been more recently established.

Other international organizations also provide assistance, such as, UNIDO, the United Nations Industrial Development Organization. The opportunities offered by DEVCO and others can be a useful building block in creating a solid national standards structure; but, as EOS knows, much more can and should be done. While EOS also participates in ISO's certification, consumer, and information committees these international efforts are only part of what is need ed.

A growing national standards body must work closely with other NSBs and with the standards groups of other countries, such as the U.S. National Bureau of Standards. Only through direct, regular contacts like this, and by working together on specific projects can relevant experience be shared and technological knowledge transferred.

The NSB must also work closely with its country's industries to encourage the same strong link that exists between industries and their standards groups in highly industrialized countries. The NSBs relationship to the industry that it serves significantly influences its contribution to its country's economic growth.

Underlying the concern for product standards and testing is the need to expand trade opportunities. As advocated by ISO leaders, attention to international standards and their adoption, where possible, will help. Finally, however, successful quality control programs for imports, exports, and products for domestic consumption, can improve Egypt's position in world trade.

In a featured speech in a forum on development assistance at the ISO World Assembly in September 1982, Dr. D. Ogun, the Director of the Nigerian Standards Organization, described the role of NSBS. Dr. Ogun spoke of his organization's efforts to improve consumer goods through use of a national certification mark; to increase safety through development of needed standards; to use international standards through their interpretation for domestic application; and to produce industrial progress through cooperative standards development. EOS should do no less and, with help and understanding by government and industry, will do much more. 
Food Standards and Qual1ty Assurance Programs at the Food and Drug Administration

\author{
Richard J. Ronk \\ Deputy Director, Bureau of Foods \\ Food and Drug Administration \\ Washington, D. C.
}

The Food and Drug Administration (FDA) has been setting either voluntary or mandatory standards and establishing sampling plans for some 75 years. I belleve these standards have been responsible in a large measure for giving us what is arguably one of the safest and most wholesome food supplies in the world. Some of these standards establish safe conditions of use for food ingredients. Others, such as Good Manufacturing Practice Regulations, outline codes of hygienic practice. Standards of 1dentity, quality, and fill of container that have been promulgated by FDA for many years, are concerned with food composition and labeling. In addition, since 1962 the United States has actively participated in the Codex Alimentarius Commission's Food Standards Program, a joint program of the Food and Agricultural Organization of the United Nations and the World Health Organization, which has labored mightly in trying to harmonize food standards world wide to facilitate international trade. Let me very briefly describe these programs this morning.

The standard setting activities of the Bureau of Foods result in the issuance of regulations which have the force and effect of law. All regulations issued are authorized by the Federal Food, Drug and Cosmetic Act (The Act). Section 401 of the Act provides for the establishment of standards of identity, quality, and fill of container when a proposed standard w1ll promote honesty and fair dealing in the 1nterest of consumers. Any interested person may petition FDA, or the Commissioner of Food and Drug may propose a new standard or an amendment to an existing one.

Proposed standards are published in the Federal Register, a daily publication of the National Archives, and comments from all interested parties are invited. Based on comments recelved and other information the Commissioner then publishes an order ruling on the proposal. Persons adversely affected by the regulation have 30 days to object and request a hearing on issues of fact. Non-contested orders become effective regulations on a specific date which cannot be less than 30 days after the order is published in the Federal Register. 
As you are aware, standards of identity define the composition of a food. They prescribe ingredients that shall be included in a particular food and those which are optional. These standards establish minimum levels for valuable or characterizing ingredients, and maximum levels for other ingredients such as water. There are prohibitions for inappropriate ingredients such as colors or nutrients in $j$ ams. Lastly, standards of identity can describe the form or styles of food permitted and establish labeling requirements.

Standards of quality define and set limits on such quality attributes as peel in tomatoes or blemishes in canned cherries. Quality standards can also provide for substandard product labeling.

Standards of fill of container set minimum fill requirements for total container contents. For certain solid foods packed in readily drainable liquids, minimum drained weight requirements may be specified. These standards also may provide for substandard product labeling.

Some of the early standards were those for canned peas, frult butters, $j$ ams and jellies and canned peaches, pears, apricots and cherries. These were followed by standards for cheeses, chocolate products, evaporated and condensed milks and many other foods. At present there are 300 food standard regulations concerning over 500 foods.

FDA's early food standards were "recipe" standards which set rigid compositional requirements and required lable delcaration of few ingredients. The first major departure from the traditional "recipe" standard approach was the "breaded shrimp" standard established in 1973. This standard requires that the food contain not less than $50 \%$ shrimp based on a specific test procedure. While it also enumerates the shapes in which the food may be marketed (e.g., round, butterfly, pieces) and prescribes labeling, it departs from tradition by providing for "safe and suitable" batter and breading material and leaves composition largely up to the manufacturer. In conjunction with this safe and suitable approach is a requirement that each optional ingredient used be declared on the label.

The "safe and suitable" ingredient approach is made possible by another provision of our law, the Food Additives Amendment of section 409 of the Act. Since the law requires that all food additives be $j u d g e d ~ s a f e$ under their conditions of use prior to the time they are marketed, the manufacturer has a positive Iist of "safe and suitable" ingredients to choose from when formulating products. 
Most of our food standards have in recent years been revised to permit "safe and suitable" options in satisfying compositional requirements and to require the label declaration of optional ingredients used. For example, flour is a mandatory ingredient in bread but the type of flour is optional. Because the type of flour may vary, the Agency requires that it be identified in the ingredient declaration.

The United States as a member of the Codex Alimentarius is obligated to review Codex standards for possible adoption. Most standards involved come within the jurisdiction of the Food and Drug Administration. There are a few, such as for meats and other animal products, that come under the jurisdiction of the U.S. Department of Agriculture; and EPA has the responsibility for pesticides. The procedure FDA uses to consider Codex standards is specified in Title 21 of the Code of Federal Regulations, Section 130.6 .

Since the Act specifically forbids promulgating standards for most fresh or dried fruits or vegetables, we are not able to adopt and enforce the recommended Codex standards for some of these products. In all other instances, however, it is the policy of FDA to favor acceptance of recommended Codex standards when a requirement for those standards can be shown to be reasonable and calculated to promote honesty and fair dealing in the interest of American consumers. We expect that most of the provisions of most Codex standards will be able to meet these conditions and the other statutory requirements of our law. There have been and will continue to be, however, many cases where the Codex standards concern a food which is not of major importance to the United States and the benefits to be expected by promulgating a standard of identity may not be substantial enough to justify such action. In this situation, we have usually declined to accept the Codex standard while advising the Secretariat that we will permit free movement of the product in our commerce so long as it meets the other requirements of our statutes and regulations.

Let me emphasize that for us to adopt a Codex standard, we must promulgate a standard of identity, quality and/or fill of container under the authority of Section 401 of the Act which incorporates provisions that are in harmony with those of the Codex standards under consideration. The language need not be identical with that of the Codex standard, but the substantive requirements will be the same where this appears appropriate.

This may cause us to promulgate new standards in some instances and to amend existing standards where our present standards differ from the Codex standards. As previously indicated, our procedures require that before we issue a food standard regulation we must publish it for review and invite comments from the food industry, consumers, academic circles and other interested persons on the overall value and desirability of adopting in whole or in part the provisions of each particular Codex standard under consideration. The Commissioner is particularly interested in recelving comments from various diverse groups. 
Currently, the Food and Drug Administration is responsible for most of the Codex Standards other than those for meat products that have been submitted to governments for acceptance. FDA has also been quite involved since the early 1960's in developing Good Manufacturing Pratice regulations. These regulations are part of a total program which makes use of the standards, developments, and Codes of hygienic practice to assure good sanitation during the food manufacturing process. The outcome of these mandatory standards development activities has been safer and better quality consumer products.

The Agency also encourages food companies to establish their own quality assurance standards and programs which cover a processing plant's sanitation practices and food processing operations. Such programs include a system of product codes that identify the source of a product and relate a particular item to production data. The plan outlines specific points in the process that warrant scheduled monitoring, and lists analytical methods to be used to evaluate material and products of concern. Specifications are defined for ingredients in plant process operations and finished goods. Flow diagrams catalog the processing steps from the acceptance of raw materials to the production and packaging of finished products for each product or group of related products.

A sound quality assurance program helps provide assurance to the processor, the consumer and the FDA that a firm's product is safe and wholesome.

A quality assurance program also helps the company to conform with all food processing regulations. Successfully implemented, it may negate the need for adverse regulatory action. FDA-initiated legal actions against products and firms, resulting from poorly controlled plant operations, can be expensive and damaging to the firm's public image and pocketbook. The recall of unacceptable food products can be more costly than the controls needed for its prevention.

We recommend that food processors periodically evaluate their quality assurance capability. If it is inadequate, measures should be taken to correct the situation. A new quality assurance plan should be developed or the present one modified. The quality assurance program the company undertakes must handle the wide range of food processing problems. It should provide the company with the assurance that it is doing the best job possible.

The Food and Drug Administration firmly believes that a quality assurance program is a company's principal consumer protection insurance policy. Without such a program, a plant can run the dangerous risk of threatening its entire production. Firms with an effective quality assurance program are able to detect and eliminate many potential food processing problems before they get out of control. 
A questionable product may not only discourage consumers from purchasing products from the firm that made them but those of other companies as well. The distribution of questionable products also causes the mandatory standards to be applied, and may create an outcry for additional mandatory standards. 

Jack E. Snell

Director

Center for Fire Research

National Bureau of Standards

Washingtor, DC 20234

This paper describes the National Bureau of Standards'

Center for Fire Research and the rationale for its

technical program. The center provides scientific and

technical information, measurement and test methods as a

basis for standards, codes and engineering practices for

fire protection. The central thrust of the prosram is

on providing the technical basis for reducing fire

losses and costs. The center undertakes collaborative progranis with domestic and foreign research

laboratories.

\section{Introduction}

The Center for Fire Research of the National Bureau of Standards was created in 1974 following passage of the Fire Prevention and Control Act to provide the scientific and technical basis for reducing U.S. fire losses and the costs of fire protection. Fire losses in the United States are among the very worst in the world. The premise of that legislation is that fundamental and applied research into all critical aspects of fire phenomena will provide the basis for costeffective means to cut U.S. fire losses and fire protection costs by more than half. Results to date affirm this premise.

This paper describes the approach being taken by the Center in meeting this objective.

\section{Fire Problem in the United States}

In 1980, United States fire deaths were 7600, nearly twice the international average on a per capita basis. An additional 200,000 persons suffered burns or other fire related injuries. These statistics reveal little of the fear, helplessness, or agony endured by these and the hundreds of thousands of other citizens assaulted annually by fire. The total cost of fire is estimated to be 21 billion dollars annually. This includes the direct costs of property loss, fire services, injury treatment, and the indirect costs of insurance overations, productivity losses, and fire resistance construction.

The fire problemi in the United States achieved national public policy status early in the last decade on publication of the report of the National Commission on Fire Prevention and Control entitled, "America Burning", and passage a year later of the Fire Prevention and Control Act. That leyislation put into place mechanisms to reduce "at least by half" rational fire losses (Appendix I).

Since then, progress has been made in reducing direct fire losses. Each year, 1400 fire deaths and 100,000 injuries have been prevented. Smoke detectors which are now installed in over half the residences of the United States, have played a lead technical role in this notable 
reduction in annual deaths and injuries. Other important technical developments during this veriod include: fire safety standaras to reduce the hazards of flammable fabrics in auparel particularly children's sleepwear, test method standards for floorins materials and mattresses, and a test method in voluntary program for ignitability of upholstered furnishings. Many oryanizations, private and public, have played crucial roles in these technical activities. Also, the Center for Hire Research of the National Bureau of standaras has been a major technical contributor to these developments.

However, losses remain high and much remains to be done to achieve this national goal. U.S. fire losses continue to exceed those of almost all other nations. Building fires account for about $0.2 \%$ of U.S. GNP - this is three times that in Japan.

The costs of fire protection exceed fire losses by a substantial margin. This problem is exacerbated by soaring construction costs, the compounding effects of testing, etc., resulting from the introduction of new materials, products, finishes, and designs, and the productivity losses resulting f'rom fires. Clearly, much remains to be done in bringing these losses and costs effectively under control.

Residential fires continue to dominate fire loss statistics. Fatalities are highest among the very young and the elderly - those least able to escape. Home heating fires now compete with smoking materials and furnishings as the number one cause of residential fires. This is particularly pronounced in the rural southern parts of the country.

Large cities in the U.S. have over twice the numbers of fires and fatalities than large cities elsewhere in the world. Typically, these are the sites of much of the nation's arson problem and most of the "large loss" fires.

Arson annually results in losses including about 1,000 lives, 3,000 injuries and $\$ 1.8$ billion in destroyed property. Total losses from "large loss" fires have increased in the last five years with the averaye loss per such fire remaining at approximately the $\$ 3$ million level. A significant component of this group is residential hotel fires such as the MGM Grand, Las Vegas Hilton, Stouffers Inn, and most recently, the Houston West Chase Hilton Hotel fire. The fact that each of these incidents involved significant numbers of deaths resulting from smoke exposure -- and, in several cases remote from the fire scene -- has raised wide-spread concern about the toxicity of fire gases.

Over the years considerable proyress has been made in reducing the scale or maynitude of the fire threat - from literally city-sized conflagrations to individual rooms or buildings. The area of principal concern now is reducing the threat to life safety from combustion products. Once means are developed to assure life safety in new and existing facilities, attention will shift presumably to bringing the total costs of fire protection well within affordable limits for their wide-spread application. 
3. Backsround to NBS Center for Fire Research ana Federal Fire Effort in the U.S.

The National Bureau of Standards has been involved in fire research for many years. During the first half of this century, fire research was engaged in developing the principles and techniques necessary for preventing the loss of entire buildings to fire. At NBS, the relationships between the amount of combustibles in a space and a maximum fire intensity were worked out through a series of full scale test fires. NBS worked closely with Underwriters Laboratories, the National Fire Protection Association, the American Society for Testing and Materials, Factory Mutual Research Corporation, and many others in developing and yaining acceptance for these ideas. This information provided the basis for the fire endurance concept one hour, two hour, four hour rating on columns, beams, and other structural members. Adoption of this technology by the building codes for large, public structures provided buildings which could and do maintain structural integrity in the severest of fires.

In the absence of means to predict fire performance, scientists concentrated their efforts on the development of "realistic" fire tests for materials that would, hopefully, reduce requirements for costly full-scale burns. These procedures typically were developed under pressures of time and political necessity following a fire disaster. Many of these have been useful, particularly for comparing. properties of different materials for the same use (for example, the ASTM E-84 Tunnel Test when limited to certain materials and uses for which it was intended). Unfortunately, this approach provides little insight into actual fire performance of materials, assemblies, designs, or systems.

The troubling characteristic of these approaches has been that they offer little guidance for the designer, product developer, fire or code official, or manager in making fire-safety decisions regarding new or different applications than those previously used. The solution to this problem--indeed the key to achieving the goal of the Fire Prevention and Control Act--is the development of scientifically-based tools to predict fire phenomena. This was recognized by the authors of that legislation. What was desired was the same capability that exists in various other areas of enfineering. Consider for example, aeronautical enfineering. Today, means exist to literally design and fly an airplane on a computer thus eliminating countless years of effort and sreatly reducing the risks and costs to society. Doing this requires research, a focal point for such an effort and the resources and institutional perspective and stability to sustain the research activity and provide leadership for the many component efforts needed.

In the fire field, then, as now, there was no place in the private sector to turn for this. No single firm or industry has the incentive to undertake such an effort. Material developers are concerned with sales and markets for products in hand. Testing laboratories have a heavy comitment to existing facilities ana practices and see no way to recoup the costs of basic research. The insurance industry likewise sees little direct benefit from investment in fundamental research--particularly if it will lead to reductions in the underwritten base. Also, since fire is so complex the risks of research 
are high and the benefits diffuse and long term. These considerations led the Consress to establish the Center for Fire Research at the National Bureau of Standards.

\section{Center for Fire Research (CFR)}

The Center f'or Fire Research is basically a research laboratory. As an element of the National Bureau of Standards, CFR produces research, measurement technolosy, data, test methods and practices. The Center for Fire Research is one of six Centers in the National Engineerint Laboratory of NBS. CFR has a staff of 111 people and FY 1983 budyet totalling 9.5 miliion dollars. Of this, approximately 6 miliion dollars is direct appropriations and another 3.5 million is recelved in reimbursements from other Federal agencies. Of the direct appropriations, 2 million dollars is used for research grants. This 2 million dollars represents the bulk of funding for fire research at universities in the United States. The Center's professional staff of 58 includes chemists, physicists, applied mathematicians, and mechanical, electrical, chemical and fire protection engineers. Guest workers from industry, universities, and foreign laboratories supplement permanent staff. International cooperative research programs are on-going with the National Research Council Fire Reserach Section in Canada, the Fire Research Station at Borehamwood in England, the Fire Research Group of CSTB in France, and the Fire Research Group of the Building Research Institute in Japan.

Close contact is maintained with technical peers in industry, the academic community, other government labs (e.g., Department of Defense, Federal Aviation Administration, Department of Energy, National Research Council-Canada, Bullding Research Institute-Japan, Borehamwood-United Kingdom, etc.), and elsewhere in NBS. CFR staff are active participants in voluntary consensus standards-writing organizations such as the National Fire Protection Association, American Society for 'Iesting and Materials, American Society for Mechanical Engineers, American National Standards Institute and in fire and building code sroups. A number of ortanizations serve as intermediaries in the dissemination of CFR's product in reducing fire loss and costs; for example, the National F1re Protection Association, the Fire Administration of the Federal Emergency Management Agency, and many other ayencies of sovernment--Department of Health and Human Services, U.S. Geoloyical Survey, Department of Transportation/Federal Aviation Administration, Department of Defense/Navy, Consumer Proauct Safety Commission, and the Department of the Interior, to name a $\mathrm{few}$.

The major beneficiaries of the Center's work are the general public, those spared the agony of loss, and the economy through reduced costs of essential fire protection services. Also, the technical programs and services of most of the intermediary organizations described above build on CFR research results. Tyuically CFR is not involved directly in f'ire safety technology development. The responsibility (and rewards) for that belong in the private sector just as the roles of administration and regulation legitimately belong elsewhere.

The Center's faclities include special test facilities for full scale and "standard room test" burns, and a number of specialized laboratories. For example, these include basic and applied research relating to performance criteria for suppression systems, studies of 
flame spread and burning behavior of products and materials, laser probes for studies relating to soot formation, and polymer

decomposition.

5. CF'R T'echnical Program Summary

Through its in-house and extramural yrants (mostly to academic and not-for-profit research institutions) programs, the Center has stimulated major advances in fundamental knowledge of fire phenomena. For example, today it is possible to predict important fire phenomena such as flashover and building smoke movement practicably and with reasonable accuracy. More importantly, these studies have demonstrated the viability of developing computer-based simulations of virtually all types of fire scenarios for the purpose of developing means to reduce fire losses and the total costs of fire protection. This is an extremely exciting and significant development.

The research base established by CFR has created for the first time a capability to predict and evaluate fire risk in quantitative terms. Technically, "fire risk" is defined as the likelihood of harm from f'ire in a specified context. Its measurement involves estimating probabilities as well as physical consequences associated with f'ire events.

The central thrust of the CFR proyram is to establish the technical vasis for fire risk assessment standards. This will enable a fiant step forward in reducing U.S. fire losses and, as importantly, open the way or reducing by as much as $50 \%$ or more the costs of fire protection in this country.

Technical Program Stratesy

In this context then, the Center's technical program is designed:

1. To promote the continued advance of fire science;

2. To promote the development and wide-spread use of scientificallybased fire protection engineering practices; and

3. To provide technical support for timely resolution of major fire safety issues/problems.

Consider each of these elements in turn:

1. Promote the Continued Advance of Fire Science

Fire science is emerging as a research discipline. Models have been developed to predict fire growth in a single compartment, the movement of snoke in a simplified "building", the thermal decomposition of a few simple materials under controlled radiant flux. Computer-based mathematical models are under development which will provide means to eluciate complex mechanisms such as flame spread on walls and ceilings, the entrainment of air and vitiated gases into a fire plume, and to predict flame extinguishment for specified application of a suppressaant, e.g., water. Soon it will be possible to predict the evolution of smoke and gas in a specified building for an assumed fire. 
All of these developments rest on the cumulative base of fundamental research built up through the in-house and extramural frant proframs of CFK. The results are beginning to come at an accelerating rate. continued uriority to fundamental research on fire phenomena is essential to attainment of the Center's goal.

Each task in the CFR program has a fundamental research component to sustain the development of fire science and as an investment for future advances. This includes staying current on advances in academic and industrial research in fire and related fields in the U.S. and at leading laboratories throughout the world.

Notable results in the area of fundamental research are expected in the 1983 to 1988 time frame. These include developing means to preaict the determinants of smoldering, in particular transition from smoldering to flaming combustion, and the determinants of soot formation. These efforts involve expanding collaborations with researchers in other NBS Centers--Applied Mathematics, Chemical Engineering, Chemical Physics, and Analytical Chemistry. Basic research in the complex fluid dynamics of fire will continue leading to better ways to characterize flame spread, rdiant ignition, and fire growth. Common terms, measurement methods and reference data are also important needs in refining Fire Science. Further bsic work in the discipline of risk analysis, carried out principally through the Center for Applied Mathematics, and extramural grants, is necessary to assure success in the development of fire risk assessment standards.

2. Promote Scientifically-Based Fire Protection Engineering Practices

The CFk program will foster substantial departures from traditional practice in fire protection. For decades, the only sure way to demonstrate the effectiveness of a fire-safety design was to "build it and burn it". In some instances, this may never be true. However, acceleratiny developments in Fire Sclence are leading to the use of scientifically-based and field-validated models of fire phenomena along with appropriate data derived from test methods of materials, assemblies, etc. This approach will greatly reduce the costs of determining fire safety performance of designs and costs of fire protection technologies themselves.

The explosive increase in capabilities of microcomputers and related technoloyy has made practical calculations that until recently were virtually inconceiveable. The success is achieving the center's goal requires not only exploiting this capability but also taking specific steps to facilitate its widespread adoption and use throughout the entire fire protection community.

Therefore, each of the Center's tasks involves coordinated efforts with intermediaries in industry and the professional community aimed at accelerating this transition to the use of scientifically-based computer models. This includes models of fire growth processes, fire suppression and extinguishment, and the generation and distribution of smoke and toxic gases in time and space.

Success will depend on the parallel development of appropriate test methods, data, and validation tests of these models. CF'R already has established collaborative ayreements with other U.S. Institutions, 
i.e., Factory Mutual Research and Underwriters Laboratories, as well as international countervart oryanizations, such as the National Research Council in Canada, the Building Research Institute in Japan and the Fire Research Station in England. Typically these other organizations have large scale fire test facilities unavailable at CFR, whereas CFR has the measurement and analytical capability needed to produce desired data.

3. Provide Technical Response to Current Fire Problems

CFR must remain responsive to urgent needs of others for technical support/expertise in solving current fire problems. For example, analysis of the major fire scenarios in the United States today draws attention to a number of immediate areas of concern:

a. Kesidential fires;

b. The effects of smoke and toxic gases. from fires;

c. The absence of practical, widely-used tools for evaluating fire risk and the effectiveness of fire protection systems for facility design or retrofit technologies;

d. Adequate, valid and timely public information on fire protection;

e. Tradition-bound fire protection institutions and technologies; and

f. Arson.

Efforts to address any of these concerns could well absorb the entire resources of the Center. Similarly, CFR's unique research capabilities would rapidly dissipate if it were to respond to every significant fire incident or public concern. Therefore, the Center carefully screens requests for assistance to determine if adequate capabilities exist elsewhere, if it can indeed make a unique contribution, or if the request provides an opportunity to develop insights needed to sharpen its research efffort.

Also, CFR supports a fire investigation program carried out by the National Fire Protection Association (NFPA). This provides immediate response and keeps CFR alert to technical issues arising in fire incidents. For example, CFR at present is working closely with New York, California, the Consumer Product Safety Commission, industry and others (e.t., NFPA and the National Institute of Building Sciences) in responding to public concerns regarding smoke toxicity. Much of the Center's work for other asencies of the Federal Government falls in this category. Appendix II contains a summary of the CFR Technical Progranı.

6. Summary

The proyrans of the Center for Fire Research are aimea at developing the technical basis for prediction of important fire related phenomena. These include materials fire performance, facility desirn for tire safety, performance evaluation of fire safety systems, of occupant response, and cost-effective risk management practices. This represents a major departure from continued reliance on historically 
developed test methods and traditional practices. We are encouraged by recent technical developments that sustest practical tools for fire safety analysis and evaluation can be developed for wide spread use within the coming aecade. Also, we are encouraged by the growing interest in other foreign centers in drawing on this technology base and in collaborating in the development of improved fire safety practices. We welcome the interest of the Egyptian National Institute for Standards in Fire Research and look forward to the prospect of a collaboration in this field. 
The Importance of Standard Reference Materials to

Industrial Quality Control

S. D. Rasberry

National Bureau of Standards

Washington, DC 20234, USA

\section{Abstract}

Industrial quality control depends on many measurement techniques beyond mere inspection. Such techniques include precise dimensional measurement, accurate determination of chemical composition, use of dye penetrants to revea 1 small cracks, and detecting hidden flaws by means of ultrasonics. These together with dozens of other techniques help to extend man's senses to perfect the quality of what he produces. This paper will examine how reference materials, for example Standard Reference Materials (SRM's) from the National Bureau of Standards, help provide accurate measurements to support industrial quality control.

\section{Introduction}

Industrial quality control is based on measurement. This leads to the question, how can one be sure that the measurements are sufficiently accurate to assure the desired level of quality? This is an important, if occasionally overlooked, question. Usually, it is invalid to assume that measurement error will be small when compared to the variability of the item being measured. This is especially true when the quality control measurements are, or depend on, analysis of chemical composition.

To say it a different way: high-quality measurements are needed before we can have quality control. How can we assure high-quality measurements? One of the most practical approaches to obtaining high quality measurements is through the use of reference materials such as the Standard Reference Materials (SRM's) certified by the National Bureau of Standards.

In general, Standard Reference Materials are well-characterized materials with specific chemical or physical properties certified by the National Bureau of Standards. For seventy-six years they have been sold by NBS, recently at the rate of about 40,000 per year, to help insure the accuracy of measurement. More than $80 \%$ of the SRM's distributed are used in industrial measurement applications such as maintaining quality control in the production of materials and goods. Of the 100 largest industrial companies in the United States, 83 purchased SRM's in a recent fiscal year. More details about SRM's are given in the first five references $(1-5)$.

SRM's are tangible, objects. In many cases they are prototypes of a commercial material--such as cement, plastic or stainless steel certified for chemical composition. Some are natural matrix materials certified for composition. In other cases SRM's support engineering 
tests, either by virtue of the properties of the materials or by the way they are fashioned. To illustrate the latter, we certify an SRM for the dimensions of several cracks, differing in width, which can be used to test the sensitivity and performance of dye penetrants used in nondestructive evaluation. We plan each material to help users validate or calibrate their measurement process. Further details on certification and use of SRM's are given in the references (6-13).

This paper is focused on use of SRM's to help assure industrial quality control. However, it is important to mention that there are also other reasons why Standard Reference Materials are produced and used. In some instances they are very important in aiding fair buyer-seller transactions. One example is the sale of stainless steel with price based on the content of chromium and nickel. Both the buyer and the seller require a fair analysis of the material--one where the accuracy of analysis is assured by reference to an impartial standard, such as the SRM's certified by NBS. In other fields, SRM's help promote accurate analyses to support clinical, nutritional, and environmental measurements.

\section{Accuracy is the Acid Test}

"Good measurements cost money, bad ones cost more. Depending on your business, bad measurements can cost much more than the original investment--and often more than money alone. They can cause wrong medical diagnosis and treatment. They can mean lost production time, waste of energy and materials, manufacturing rejects, and product liability problems. They can bring opposing parties to court over commercial, environmental, health and safety issues. On the positive side, good measurement is a key to productivity (1)."

Figure 1 illustrates the main explicit pathways technologists follow in supporting quality assurance measurements. The figure shows that quality assurance can be supported indirectly (single line) by "traceability" to Standard Reference Materials; but a better approach is "accuracy" in measurements (shown by triple lines). Accuracy in measurements should be based either on first principles of science or on national standards which are based on first principles of science. Obviously, in practice, the two main branches are not so clearly separable. Whenever a measurement program design is explicitly defined in terms of traceability, accuracy considerations are usually included or at least implied. Similarly, even if the design is based on meeting accuracy criteria, traceability considerations are usually spelled out or implied. The point here is that accuracy is the preferred pathway and that traceability requirements should support that approach.

\section{Characteristics of SRM's}

Where possible, NBS certifies commercial values of the properties under investigation as accurate values. That is, they are the "true values" within the stated overall uncertainty limits. During the mid-1970's, considerable time and effort were invested in refining the technology of certification. These efforts have been continued into the $1980^{\prime} \mathrm{s}$ with increased international participation. 

SRM :

In general, four major considerations are involved in certifying an

Homogeneity. It is essential that every subportion of a given lot be the same within the overall uncertainty limits provided. This is necessary to ensure that each user obtains a portion of the SRM which agrees, in values certified, with the certificate.

Stability. If the material changes with time (and certainly most materials do to some extent) it will eventually have "true values" that no longer agree with the values printed on the certificate. Increasingly, SRM's are provided with expiration dates, after which their certificate is not valid. (For example, no clinical SRM is issued with a certificate valid for more than five years.)

Handling Procedures. Special procedures, such as cold storage, drying and other preparation, may be necessary to the proper use of SRM's. Such instructions are now provided routinely when appropriate.

Certified Values. The importance of accurately analyzing materials so that "true value" numbers can be placed on the certificate is clear, but this is our most difficult job at NBS. We do not claim infallibility. Even though systematic errors in the measurements leading to certification are always investigated, later advances in the state of the art may uncover errors that were undetected at the time of the original work. Thus, NBS tries to provide conservatively stated uncertainties to allow for unknown systematic errors. Several techniques are especially helpful in the quest for certification accuracy.

First, although they may be much too costly for routine use, methods based on first principles of science (methods of the highest accuracy) are linked to basic measurement units and thus reduce opportunities for error. Second, the agreement of several independent methods lends assurance to certification. Further, agreement among several independent laboratories--using the same or different methods--provides additional reason for confidence. Assistance in certification is provided by many independent laboratories. Increasingly, the coordination of this assistance has been accomplished with the help of the American Society for Testing and Materials, through research associate agreements. There are such agreements in effect in the fields of metals and ores, glass, and particle metrology; additionally, the cooperation of other associations has been most helpful. Some of those cooperating in the production of SRM's are the Atomic Industrial Forum, the Motor Vehicle Manufacturers Association, the American Iron and Steel Institute, the American Foundrymen's Society and the Portland Cement Association.

IV. SRM'S ARE USED FOR CALIBRATION OR VALIDATION

Where enough SRM's of a given type are available, they can provide calibration points for industrial chemical analysis and other types of 
industrial measurements. For example, steel analysts employ the well known 1100 series and 1200 series SRM's for low alloy steel x-ray fluorescence analysis. With a relative method, like $x$-ray fluorescence, good calibration standards are crucial. Certainly, when not enough SRM's are available from NBS to calibrate an instrument, SRM's may be used together with other reference materials to produce the best possible calibration.

Figure 2 shows a linear regression calibration where SRM's have been used to determine the relationship between intensity measured in the instrument and concentration of an element in different materials.

Some instruments and methods have calibrations based on first principles. Here no "type standards" are required--calibrations may be based on pure element standards or at most binary mixtures of pure element standards. A very important role for Standard Reference Materials emerges with the increased use of such methods--the role of method validation.

To serve as a validator, the SRM is not used at all during instrument calibration. Instead, it is measured right along with the unknowns. It is placed on the graph as unknown and the results are compared with certified values to confirm or deny the validity of the measurement process.

In virtually all uses of SRM's in industrial quality control, they are used for calibration or validation of measurement methods. In either case this leads to greater accuracy of measurement. In turn, accurate measurements support better quality and safer products, regardless of whether the product is a steel girder, a glass bottle or a concrete building.

\section{Available SRM's}

The NBS inventory of SRM's contains about 900 different types of materials in about 50 categories, as shown in Table I. Although the decade of the $70^{\prime} \mathrm{s}$ saw considerable emphasis on producing environmental, energy-related, biological, and clinical laboratory SRM's, most of the production effort is still concentrated on materials of industrial interest. About 350 metals, ores, cements and ceramics are available, for instance. SRM's have been issued, or are on the way, to support micro-dimensional metrology, including particle size analysis. Linewidth standards for very large scale integration (VLSI) semiconductor production and silicon resistivity SRM's are highlights of the recent production program.

Coating thickness, eddy current, and dye penetrant SRM's support the growing field of nondestructive evaluation. SRM's for surface roughness, wear debris and lubricating properties of oil are on the way. Quality control SRM's are available for such industries as metal, mining, cement, chemical, plastic, rubber, glass, and ceramics. Other categories in Table 1 indicate the kinds of generic measurements which are supported by SRM's. Details on specific items are found in the 
catalog (2) and other reports, (3-5) or by calling the office of Standard Reference Materials at (301) 921-2045.

Table 1. SRM Categories

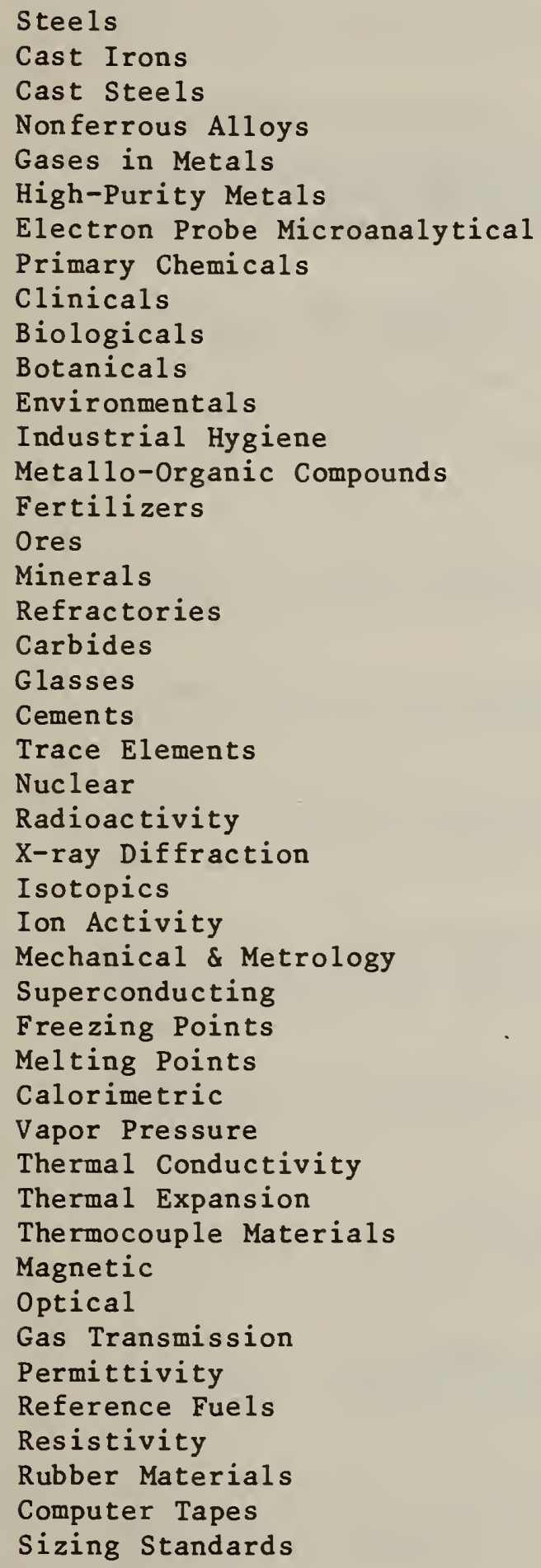




\section{Table 1. Continued}

Color

Photographic

Surface Flammability

Smoke Density

Water Vapor Permeance

Table 2 is a list of SRM types where certification effort is underway or anticipated during the $1980^{\prime} \mathrm{s}$. Of course all of this work must be carried out while recertifying new lots of material to replace the approximately 150 types which are exhausted in supply each year.

Table 2. Some major new SRM needs forecast for the 1980 's

\section{Compositional SRM's}

Trace Organic Analysis

--Organic pollutants in natural matrices

--Nutrients and toxic substances in food and agricultural products

--Enzymes, individual proteins, and therapeutic drugs in human serum

--Additives in plastics

Trace Elemental Analysis

--High-performance alloys

--Plastics

--Glass and ceramic materials

--Semiconductor materials

--Fibers

Bulk Compositional Analysis

--Recycled materials

--Uranium and plutonium nuclear fuels (for nuclear safeguards)

--Fibers

--Quantification of inorganic chemical species

\section{Physical Property SRM's}

\section{Density Standards}

Dimensional Standards

--Electron microscope magnification

--Particle sizing 
Table 2. Continued

Voltage Standards (Josephson Junction)

Optical Properties

--Fluorescence

--Stray light

--Reflectance

--Wavelength

VI. References

[1] Standard Reference Materials, Information booklet available on request to the Office of Standard Reference Materials, National Bureau of Standards, Wash., D.C. 20234 (1982).

[2] Catalog of NBS Standard Reference Materials, NBS Spec. Pub1. 260, Government Printing Office, Wash., D.C. 20402 (1981-83 ed.).

[3] Alvarez, R., Rasberry, S.D. and Uriano, G.A., NBS Standard Reference Materials: Update 1982, Anal. Chem. 54, No. 12, (1982) 1226A.

[4] Uriano, G.A. and Rasberry, S.D. Eds., 1981 Annual Report-Office of Standard Reference Materials, NBSIR 81-2447, NBS, Wash., D.C., $(1981)$.

[5] Rasberry, S.D., Ed., Reference Materials, monthly column appearing in American Laboratory $\underline{12}, \underline{13}, \underline{14}$, June 1980 to present.

[6] Seward, R.W., Ed., Proceedings of the Symposium on Standard Reference Materials and Meaningful Measurement, NBS Spec. Publ. 408, Government Printing Office, Wash., D.C. 20402 (1975).

[7] Cali, et al., The Role of Standard Reference Materials in Measurement Systems, NBS Monograph 148, Government Printing Office, Wash., D.C. 20402 (1975).

[8] Uriano, G.A. and Gravatt, C.C., The Role of Reference Materials and Methods in Chemical Analysis, CRC Crit. Rev. in Anal. Chem. 6, (1977) 361.

[9] Schmitt, B.F., Ed., Production and Use of Reference Materials, Proceedings of the International Symposium held at Bundesanstalt fur Materialprufung, Berlin 45, F. R. Germany, (1980).

[10] Rasberry, S.D., Standard Reference Materials for Physical Measurement Traceability, National Conference of Standards Laboratories Newsletter 20 , No. 4 (1980) 23.

[11] ISO Guide 30-1981 (E), Terms and definitions used in connection with reference materials, Avail.: American National Standards Institute, New York, N.Y. (1981). 
[12] ISO Guide 31-1981 (E), Contents of certificates of reference materials, Avail: American National Standards Institute, New York, N.Y. (1981).

[13] Juran, J.M., et al., Eds., Quality Control Handbook, Third Edition, McGraw-Hill, New York, N.Y. (1974). 


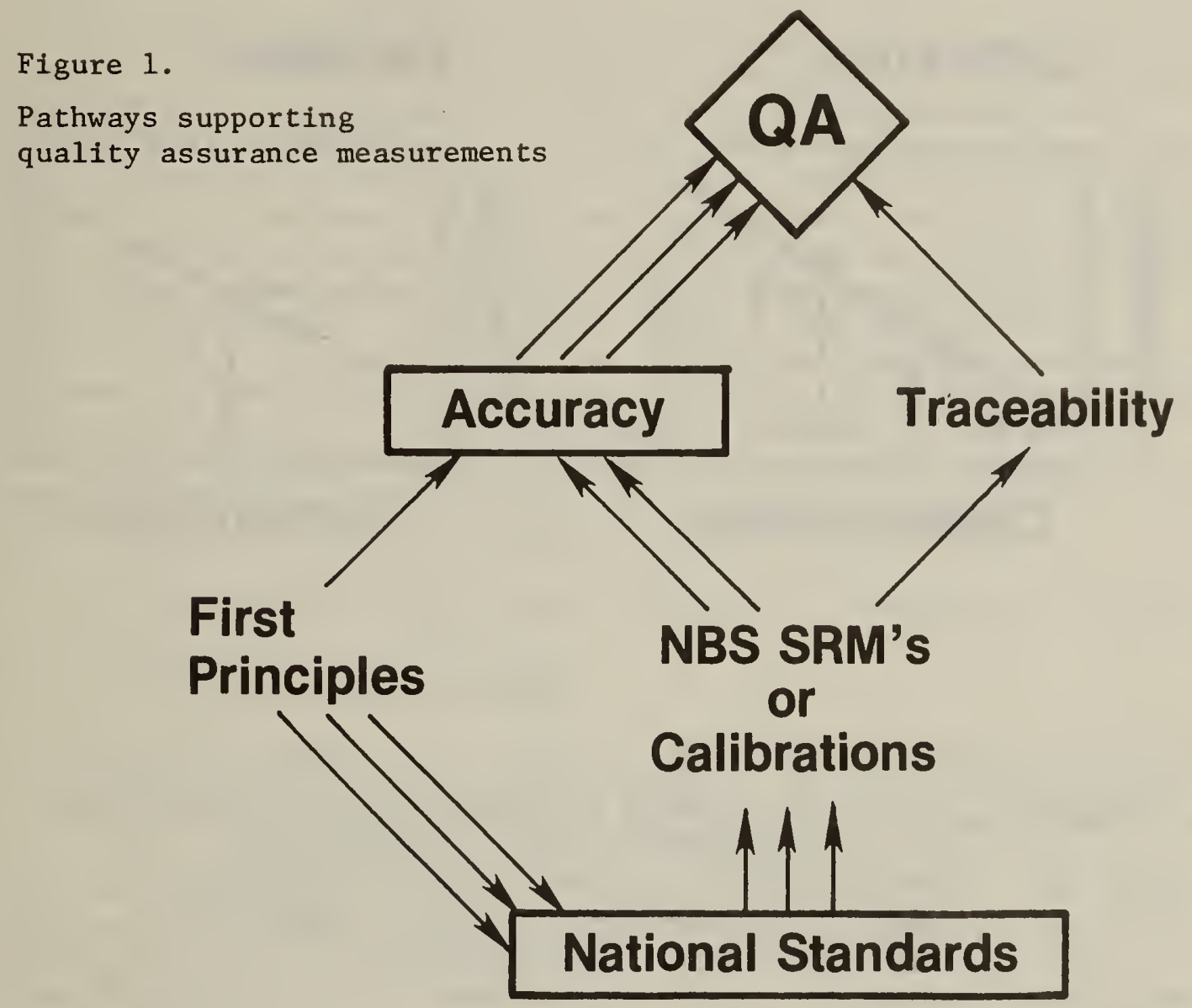




\section{SRM's}

\section{Calibration}

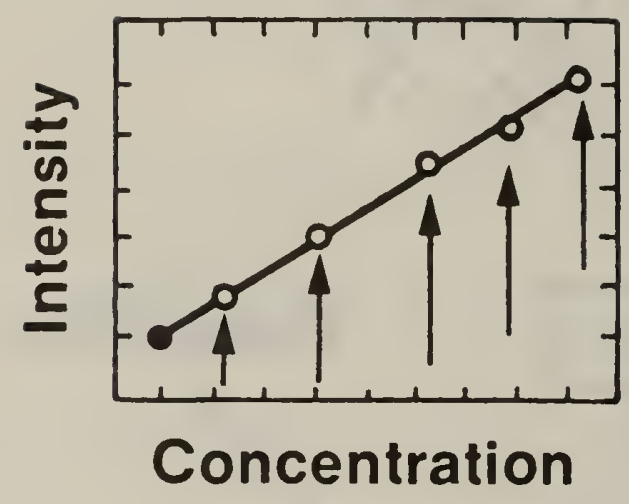

Validation

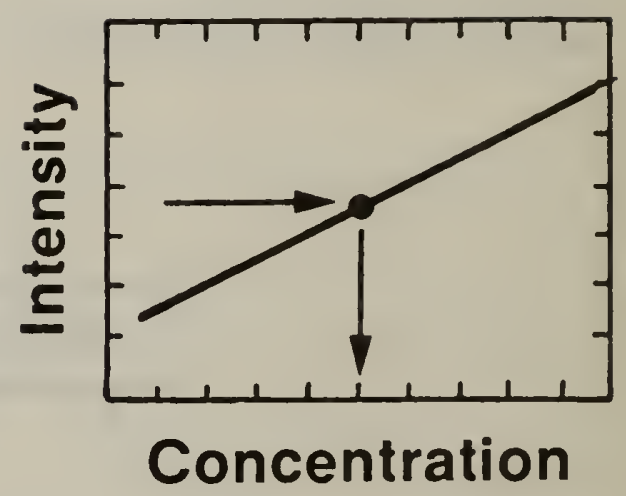

Figure 2. On the left, SRM's are used to determine the shape of the relationship between intensity and concentration. On the right, the SRM is measured as an unknown to see if the correct analytical result is produced. 
International Programs of the U.S. National Bureau of Standards

\author{
Kurt F. J. Heinrich \\ Chlef, Office of International Relations \\ National Bureau of Standards \\ Washington, D.C.
}

The National Bureau of Standards (NBS) was created in 1901 by the Congress of the United States in order to establish a focal point for establishing standards for all measurements of importance to the economic and technological 1 ife of the nation. To measure a property of a material or object, both the nature of what is measured and the technique of measurement must be known. Therefore, the role of NBS requires us to do research in physics, chemistry and materials sciences, in various branches of engineering, and in metrology, that is, the science of measuring. No other U.S. Federal institution covers so wide a range of research activities. These are primarily related to national, rather than international, problems. However, the laws of sclence and the art of measurement are of interest to all nations; therefore to achieve the goals of NBS we must carry on friendly and constructive interaction of mutual benefit with institutions of other nations which have interests similar to those of NBS.

The international activities of NBS can be classified as follows:

\title{
- Multinational Interactions:
}

NBS is the representative agency for the United States of America in two international intergovernmental bodies. The first and oldest is the International Bureau of Weights and Measures, created by the Treaty of the Meter, which ensures that the definitions of the fundamental units of measurement, such as of length, time, mass, etc., are compatible among all member countries. The Director of NBS is a member of the International Committee of Welghts and Measures which decides the issues pertinent to the Treaty of the Meter, and NBS has contributed substantially to the metrological developments which find their expression in the resolutions of this Committee. Egypt is also a signatory member of this treaty, and is represented by the National Institute for Standards. Dr. Ambler and Dr. Dawoud have just returned from the 17 th General Conference of Weights and Measures in Parls. The second organization in which NBS is involved is the International Organization of Legal Metrology (OIML), which has been established in order to reach international agreement on standards for measuring instruments and their use in international trade. 
Seismic Effects and Fire Research in Japan and Yugoslavia, and on other subjects such as, for instance, corrosion, with diverse $n$ institutes in Yugoslavia, Spain, Egypt, and other countries.

\section{- Training and technical assistance}

NBS has no formally organized facilities or programs for training of technicians or junior scientists. However, in special cases, programs have been instituted with institutions such as the Instituto de Pesquis as Tecnologicas (IPT) in Sao Paulo, Brazil, Korea Standards Research Institute (K-SRI) in South Korea, as well as with the Egyptian National Institute for Standards and the Egyptian Organization for Standardization and Quality Control, which include the improvement of skill of technical personnel. In such cases the programs are structured so as to fit as much as possible within the normal technical tasks of NBS, so that the work load of the laboratories is not unduly increased. It is our experience that for persons with the appropriate technical background, such hands-on experience is the quickest way to absorb the specific skills they wish to learn.

Technical assistance was also offered to some of these institutions in the preparation of specifications for the acquisition of equipment, and through visits of NBS personnel to the respective laboratories. A typical sequence within a program may include a preliminary visit of an NBS expert to the laboratory abroad to discuss programs and equipment needs, the writing of equipment specifications by both partners, a stay of several months of the foreign scientist at the NBS facilities, the acquisition of equipment by the foreign institution, and a final visit of the NBS expert after installation and calibration of the equipment.

\section{- Interaction with individuals: guest scientists.}

The National Bureau of Standards receives every year a large number of scientists who perform temporary assignments at our laboratories, in cooperation with our technologists, and within the normal activities of NBS. While most of these guest scientists come from American institutions, we have at present at any time about 80 foreign guest scientists in our laboratories, for periods which typically vary from six to eighteen months.

The status of the guest scientists is individually established by agreement of their home employers and the respective laboratory at NBS, and acceptance. is conditional to the opportunity of placing them in the laboratories within the normal task plans of the respective unit. The guest scientists are not employees of NBS; their salaries and expenses are normally provided by their home institutions or by national or international organizations which finance the exchange of scientists (e.g., UNIDO, NSF, etc.). In exceptional cases, the operating divisions of NBS may be authorized to contribute to expenses, but no salaries are paid, and the office of International Relations has no central funds for the maintenance of these or other international activities. 
NBS is active in areas of standardization and definitions which are handled in international organizations the members of which are not by definition governmental agencies, such as the International organization for Standards (ISO), the International Union for Pure and Applied Physics (IUPAP) and Chemistry (IUPAC), and the International Union of Testing and Research Laboratories for Materials and Structures (RILEM). The participation is on an individual, rather than an institutional, basis. NBS encourages its scientists to participate as members of the many committees established within the framework of such organizations. Such individual participations parallel those of NBS employees in the standards writing committees of the American Soclety of Testing and Materials (ASTM) and other institutions of national scope which are essential to the structure of the American system of voluntary standards.

\section{- Cooperation with sister institutes in other countries:}

In practically every country there is one or more laboratories with missions similar to that of NBS, and the benefits from maintaining close contacts between such institutions are very significant. Many such contacts operate within the framework of the international organizations mentioned previously, but it is equally important that bilateral cooperation be established with individual institutes with which we share common interests. Such interactions can take the form of short $v$ isits, exchange of personnel for longer perlods, or formal plans of cooperation in specified areas. There is, and must be, a constant flow of information between NBS and such institutions, and between their laboratories and scientists. It is our experience that such relations are most fruitful when they can be maintained with a minimum of formality, and at all appropriate operative levels, from institute directors to researchers. On the other hand, formal agreements frequently ensure a continuity of effort, and define the financial arrangements. NBS has very flexible policies with regard to such arrangements, which ultimately benefit not only the institutions involved but also international scientific and trade cooperation.

\section{- Cooperation with other foreign institutions:}

While all nations have centers of metrology and calibration, no two of these institutions have exactly the same structure and programs. Historical reasons, special demands of government and industry, and legal definitions in the various countries of responsibilities in measurement, standards, and quality control, determine the range of activities in each case. For this reason, the National Bureau of Standards shares some of 1 ts 1 interests and research goals with many foreign institutions other than 1ts sister agencies. Thus, we interact with universities and other institutes concerned with Wind and 
- Standard Reference Materials and data, and calibrations:

While NBS does not engage in contracted work for the private sector in the development of proprietary projects, it performs activities for interested persons or institutions against payment of fees in the following three flelds: it provides Standard Reference Materials (SRM's), as described in the communication by $S$. Rasberry, and standard reference data, on physical or chemical properties, and it provides calibration in certain areas such as electrical units and thermometry for which NBS is considered specially qualified. NBS has specific authority from Congress to perform such services also for clients abroad; for instance, about one fourth of the sales of Standard Reference Materials are outside the United States.

The extent to which these services are performed is limited by facilities and manpower. NBS will not undertake routine calibrations, and services for clients abroad are rendered only when they have ascertained that equivalent local sources of calibration are not avallable. It is much preferable for all parties concerned that such local institutions be capable of performing calibration tasks themselves, and it is the full intent of NBS to assist our friends abroad where appropriate to perfect and maintain operative such local institutions.

Questions concerning international activities of NBS should be directed to the following address:

Office of International Relations

National Bureau of Standards

Washington, DC, 20234, USA 
Public Law 93-498

93 rd Congress, S. 1769

October 29, 1974

\section{An Act}

'To reduce losses of lift and property, through better fire prevention and control, and for other purposes.

Be it rnacted by the Senate and House of Representatives of the United States of America in Congress assembled, That this Act may be cited us the "Federal Fire Prevention and Control Act of 1974".

FINDINGS

SEc: 2. The Congress finds that-

(1) The National Commission on Fire Prevention and Control, established pursuant to Public Law 90-259, has made an exhaustive and comprehensive examination of the Nation's fire problem, has made detailed findings as to the extent of this problem in terms of human suffering and loss of life and property, and has made ninety thoughtful recomnendations.

(2) The United States today has the highest per capita rate of death and property loss from fire of all the major industrialized nations in the world.

(3) Fire is an undue burden affecting all Americans, and fire also constitutes a public health and safety problem of great dimensions. Fire kills 12,000 and scars and injures 300,000 Americans each year, including 50,000 individuals who require extended hospitalization. Ilmost $\$ 3$ billion worth of property is destroyed annually by fire, and the total economic cost of destructive fire in the United States is estimated conservatively to be $\$ 11,000,000,000$ per year. Firefighting is the Nation's most hazardous profession.

(4) Such losses of life and property from fire are unacceptable to the Congress.

(5) While fire prevention and control is and should remain a State and local responsibility, the Federal Government must help if a significant reduction in fire losses is to be achieved.

(6) The fire servicc and the civil defense program in each locality would both benefit from closer cooperation.

(7) The Nation's fire problem is exacerbated by (A) the indifference with which some Americans confront the subject; (B) the Nation's failure to undertake enough research and development into fire and fire-related problems; (C) the scarcity of reliable data and information; (D) the fact that designers and purchasers of buildings and products generally give insufficient attention to fire safety; (E) the fact that many communities lack adequate building and fire prevention codes; and (F) the fact that local fire departments spend about 95 cents of every dollar appropriated to the fire services on efforts to extinguish fires and only about 5 cents on fire prevention.

(8) There is a need for improved professional training and education oriented toward improving the effectiveness of the fire services, including an increased emphasis on preventing fires and on reducing injuries to firefighters.

(9) A national system for the collection, analysis, and dissemination of fire data is needed to help local fire services establish research and action priorities.

(10) The number of specialized medical centers which are properly equipped and staffed for the treatment of burns and the rehabilitation of victims of fires is inadequate.

(11) The unacceptably high rates of death, injury, and property loss from fire can be reduced if the Federal Government establishes a

Federal P1ro

Prevention and Control hot of 1974. 15 USC 2201 note.

15 USC 2201.

15 USC 2781 notes. 
coordinated program to support and reinforce the fire prevention and control activities of State and local governments.

PURPOSES

15 USC 2202.

SEC. 3. It is declared to be the purpose of Congress in this Act to-

(1) reduce the Nation's losses caused by fire through better fire prevention and control;

(2) supplement existing programs of research, training, and education, and to encourage new and improved programs and activities by State and local governments;

(3) establish the National Fire Prevention and Control Administration and the Fire Research Center within the Department of Commerce; and

(4) establish an intensified program of research into the treatment of burn and smoke injuries and the rehabilitation of victims of fires within the National Institutes of Health.

\section{DEFINITIONS}

15 USC 2203.

SEc. 4. As used in this Act, the term-

(1) "Academy" means the National Academy for Fire Prevention and Control;

(2) "Administration" means the National Fire Prevention and Control Administration established pursuant to section 5 of this Act;

(3) "Administrator" means the Administrator of the National Fire Prevention and Control Administration;

(4) "fire service" means any organization in any State consisting of personnel, apparatus, and equipment which has as its purpose protecting property and maintaining the safety and welfare of the public from the dangers of fire, including a private firefighting brigade. The personnel of any such organization may be paid employees or unpaid volunteers or any combination thereof. The location of any such organization and its responsibility for extinguishment and suppression of fires may include, but need not be limited to, a Federal installation, a State, city, town, borough, parish, county, fire district, fire protection district, rural fire district, or other special district. The terms "fire prevention", "firefighting", and "firecontrol" relate to activities conducted by a fire service;

(5) "local" means of or pertaining to any city, town, county, special purpose district, unincorporated territory, or other political subdivision of a State;

(6) "Secretary" means the Secretary of Commerce; and

(7) "State" means any State, the District of Columbia, the Commonwealth of Puerto Rico, the Virgin Islands, the Canal Zone, Guam, American Samoa, the Trust Territory of the Pacific Islands and any other territory or possession of the United States.

FGTABIISHMENT OF THE NATIONAL FIRE PREVENTION AND CONTROL ADMNNISTRATION

15 USC 2204.

Sec. 5. (a) Establishment of Administration.-There is hereby established in the Department of Commerce an agency which shall be known as the National Fire Prevention and Control Administration.

(b) Administrator.-There shall be at the head of the Administration the Administrator of the National Fire Prevention and Control Administration. The Administrator shall be appointed by the Presi- 
dent, by and with the advice and consent of the Senate, and shall be compensated at the rate now or hereafter provided for level IV of the Executive Schedule pay rates (5 U.S.C. 5315). The Administrator shall report and be responsible to the Secretary.

(c) Deputy Administrator.- There shall be in the Administration a Deputy Administrator of the National Fire Prevention and Control Administration who shall be appointed by the President, by and with the advice and consent of the Senate, and who shall be compensated at the rate now or hereafter provided for level $V$ of the Executive Schedule pay rates (5 U.S.C. 5316). The Deputy Administrator shall perform such functions as the Administrator shall from time to tirne assign or delegate, and shall act as Administrator during the absence or disability of the Administrator or in the event of a vacancy in the office of Administrator.

\section{PUBLIC EDUCATION}

SEC: 6. The Administrator is authorized to take all steps necessary to educate the public and to overcome public indifference as to fire and fire prevention. Such steps may include, but are not limited to, publications, audiovisual presentations, and demonstrations. Such public education efforts shall include programs to provide specialized information for those groups of individuals who are particularly vulnerable to fire hazards, such as the young and the elderly. The Administrator shall sponsor and encourage research, testing, and experimentation to determine the most effective means of such public education.

\section{NATIONAL ACADEMY FOR FIRE PREVENTION AND CONTROL}

Sec. 7. (a) Establishment.-The Secretary shall establish, at the earliest practicable date, a National Academy for Fire Prevention and Control. The purpose of the Academy shall be to advance the professional development of fire service personnel and of other persons engaged in fire prevention and control activities.

(b) Superintendent.- The Academy shall be headed by a Superintendent, who shall be appointed by the Secretary. In exercising the powers and authority contained in this section the Superintendent shall be subject to the direction of the Administrator.

(c) Powers of Superintendent.-The Superintendent is authorized to-

(1) develop and revise curricula, standards for admission and performance, and criteria for the awarding of degrees and certifications;

(2) appoint such teaching staff and other personnel as he determines to be necessary or appropriate;

(3) conduct courses and programs of training and education, as defined in subsection (d) of this section;

(4) appoint faculty members and consultants without regard to the provisions of title 5, United States Code, governing appointments in the competitive service, and, with respect to temporary and intermittent services, to make appointments to the same extent as is authorized by section 3109 of title 5, United States Code;

(5) establish fees and other charges for attendance at, and subscription to, courses and programs offered by the Academy. Such fees may be modified or waived as determined by the Superintendent;

(6) conduct short courses, seminars, workshops, conferences, and similar education and training activities in all parts and localities of the United States; 
(7) enter into such contracts and take such other actions as may be necessary in carrying out the purposes of the Academy; and

(8) consult with officials of the fire services and other interested persons in the exercise of the foregoing powers.

(d) Program of the Academy.-The Superintendent is authorized to-

(1) train fire service personnel in such skills and knowledge as may be useful to advance their ability to prevent and control fires, including, but not limited to-

(A) techniques of fire prevention, fire inspection, firefighting, and fire and arson investigation;

(B) tactics and command of firefighting for present and

future fire chiefs and commanders;

(C) administration and management of fire services;

(D) tactical training in the specialized field of aircraft

fire control and crash rescue;

(E) tactical training in the specialized field of fire control

and rescue aboard waterborne vessels; and

(F) the training of present and future instructors in the

aforementioned subjects;

(2) develop morlel curricula, training programs, and other educational materials suitable for use at other educational institutions, and to make such materials available without charge;

(3) develop and adininister a program of correspondence courses to advance the knowledge and skills of fire service personnel;

(4) develop and distribute to appropriate officials model questions suitable for use in conducting entrance and promotional examinations for fire service personnel; and

(5) encourage the inclusion of fire prevention and detection technology and practices in the education and professional practice of architects, builders, city planners, and others engaged in design and planning affected by fire safety problems.

(e) Technical Assistance.-The Administrator is authorized, to the extent that he determines it necessary to meet the needs of the Nation, to encourage new programs and to strengthen existing programs of education and training by local fire services, units, and departments, State and local governments, and private institutions, by providing teclinical assistarice and advice to-

(1) vocational training programs in techniques of fire prevention, fire inspection, firefighting, and fire and arson investigation;

(2) fire training courses and programs at junior colleges; and

(3) four-year degree programs in fire engineering at colleges and universities.

Finanolal essistanoo.

Post, p. 1545. (f) Assistance.-The Administrator is authorized to provide issistance to State and local fire service training programs through grants, contracts, or otherwise. Such assistance shall not exceed 4 per centum of the amount authorized to be appropriated in each fiscal year pursuant to section 17 of this Act.

(g) Site Selection.-The Academy shall be located on such site as the Secretary selects, subject to the following provisions:

(1) The Secretary is authorized to appoint a Site Selection Board consisting of the Academy Superintendent and two other members to survey the most suitable sites for the location of the Academy and to make recommendations to the Secretary.

(2) The Site Selection Board in making its recommendations and the Secretary in making his final selection, shall give consideration to the training and facility needs of the Academy, environ- 
mental effects, the possibility of using a surplus Government facility, and such other factors as are deemed important and relevant. The Secretary shall make a final site selection not later than 2 years after the date of enactment of this Act.

(h) Construction Costs.-()f the sums authorized to be appropriated for the purpose of implementing the programs of the Administration, not more than $\$ 9,000,000$ shall be available for the construction of facilities of the Academy on the site selected under subsection (g) of this section. Such sums for such construction shall remain available until expended.

(i) Educational and Probessional Assistance.-The Administrator is authorized to-

(1) provido stipends to students attending Academy courses and programs, in amounts up to 75 per centum of the expense of attendance, as established by the Superintendent;

(2) provide stipends to students attending courses and nondegree training programs approved by the Superintendent at universities, colleges, and junior colleges, in amounts up to 50 per centum of the cost of tuition;

(3) make or enter into contracts to make payments to institutions of higher education for loans, not to exceed $\$ 2,500$ per academic year for any individual who is enrolled on a full-time basis in an undergraduate or graduate program of fire research or engineering which is certified by the Superintendent. Loans under this paragraph shall be made on such terms and subject to such conditions as the Superintendent and each institution involved may jointly determine; and

(4) establish and maintain a placement and promotion opportunities center in cooperation with the fire services, for firefighters who wish to learn and take advantage of different or better career opportunities. Such center shall not limit such assistance to students and graduates of the Academy, but shall undertake to assist all fire service personnel.

(j) Board of Visitors.--Upon establishment of the Academy, the Secretary shall establish a procedure for the selection of professionals in the field of fire safety, fire prevention, fire control, research and development in fire protection, treatment and rehabilitation of fire victims, or local government services management to serve as members of a Board of Visitors for the Academy. Pursuant to such procedure, the Secretary shall select eight such persons to serve as members of snch Board of Visitors to serve such terms as the Secretary may prescribe. The function of such Board shall be to review annually the program of the Academy and to make comments and recommendations to the Secretary regarding the operation of the Academy and any improvements therein which such Board deems appropriate. Each member of such Board shall be reimbursed for any expenses actually incurred by him in the performance of his duties as a member of such Board.

(k) Accrenitation.- The Siperintendent is authorized to establish Committee on a Committee on Fire Training and Education which shall inquire into Firo Training and make recommendations regarding the desirability of establishing and Eduoation. a mechanism for accreditation of fire training and education programs Establishment. and courses, and the role which the Academy should play if such a mechanism is recommended. The Committee shall consist of the Superintendent as Chairman and eighteen other members appointed by the Administrator from among individuals and organizations possessing special knowledge and experience in the field of fire training and education or related fields. The Committee shall submit to the Adminis- Report to trator within two years after its appointment, a full and complete Administrator. 
report of its findings and recommendations. Upon the submission of such roport, the Committee shall cease to exist. Each appointed mennber of the Committee shall be reimbursed for expenses actually incurred in the performance of his duties as a member.

(1) Admrssion.-The Superintendent is authorized to admit to the courses and programs of the Academy individuals who are members of the firefighting, rescue, and civil defense forces of the Nation and such other individuals, including candidates for membership in these forces, as he determines can benefit froin attendance. Students shall be admitted from any State, with due regard to adequate representation in the student body of all geographic regions of the Nation. In selecting students, the Superintendent nıy seek nominations and advice from the fire services and other organizations whicls wish to send students to the Academy.

\section{FIRE TECIINUIOOY}

15 USC 2207.

Sec. 8. (a) Technology I)evelopment Program.-The Administrator shall conduct a continuing program of developinent, testing, and ovaluation of equipment for use by the Nation's fire, rescue, and civil defense services, with the aim of inaking available improved suppression, protective, auxiliary, and warning devices incorporating the latest technology. Attention shall be given to the standardization, compatibility, and interchangeability of such equipment. Such development, testing, and evaluation activities shall include, but need not be limited to-

(1) safer, less cumbersome articles of protective c'othing: including helnets, boots, and coats;

(2) bleathing apparatus with the necessary duration of service, reliubility, low weight, and ease of operation for practical use ;

(3) safe and reliable auxiliary equipment for $11 s e$ in fire prevention, detection, and control, such as fire location detectors, visual and audio conmunications equipment, and mobile equipment;

(4) special c'othing and equipment needed for forest fires, brush fires, oil and gasoline fires, aircraft fires and crash rescue, fires occurring aboard waterborne vessels, and in other special firefighting situations;

(5) fire detectors and related equipment for residential use with high sensitivity and reliability, and which are sufficiently inexpensive to purchase, install, and maintain to insure wide accentance and use;

(6) in-place fire prevention systems of low cost and of incrensed reliability and effectiveness;

(7) methods of testing fire a'arms and fire protection clevices und systems on a non-interference basis;

(8) the development of purchase specifications, standards, and acceptance and validation test procedures for all such equipment and devices; and

(9) operation tests, demonstration projects, and fire investigations in support of the activities set forth in this section.

(b) Lrmitation.- The Administration shall not engage in the manufacture or sale of any equipment or device developed pursuant to this section, except to the extent that it deems it necessary to adequately develop, test, or evaluate such equipment or device.

(c) Management Studres.-(1) The Administrator is authorized to conduct, directly or through contracts or grants, studies of the operations and management aspects of fire services, utilizing quantitative techniques, such as operations research, management economics, cost effectiveness studies, and such other techniques and methods as 
may be applicable and useful. Such studies shall include, but need not be limited to, the allocation of resources, the optimum location of fire stations, the optimum geograplical area for an integrated fire service, the manner of responding to alarms, the operation of city wide and regional fire dispatch centers, firefighting under conditions of civil disturbance, and the effectiveness, frequency, and methods of building inspections.

(2) The Administrator is authorized to conduct, directly or through contracts or grants, research concerning the productivity and efficiency of fire service personnel, the job categories and skills required by fire services under varying conditions, the reduction of injuries to fire service personnel, the most effective fire prevention programs and activities, and techniques for accurately measuring and analyzing the foregroing.

(3) The Administrator is authorized to conduct, directly or through contracts, grants, or other forms of assistance, development, testing, and demonstration projects to the extent deemed necessary to introdice and to encourage the acceptance of new technology, standards, operating methods, command techniques, and management systems for ntilization by the fire services.

(4) The Administrator is authorized to assist the Nation's fire services, directly or through contracts, grants, or other forms of assistance, to measure and evaluate, on a cost-benefit basis, the effectiveness of the programs and activities of each fire service and the predictable consequences on the applicable local fire services of coordination or combination, in whole or in part, in a regional, metropolitan, or statewide fire service.

(d) Rurai, Assistance.-The Adininistratol is authorized to assist the Nation's fire services, directly or through contracts, grants, or other forms of assistallce, to sponsor and encourage research into approaches, techniques, systems, and equipment to improve fire prevention and control in the rural and remote areas of the Nation.

(e) Coorpination.- In establishing and conducting programs mnder this section, the Administrator shall take full advantage of applicable technological developments made by other departments and agencies of the Federal Government. by State and local governments, and by business, industry, and nomprofit associations.

\section{NATIONAL FIRE D.TTA CENTER}

Src. 9. (a) Greneral. - The Adninistrator shall operate, directly or throngh contracts or grants, an integrated, comprehensive National Fire Data Center for the selection, analysis, publication, and dissemination of information related to the prevention, occurrence, control, and results of fires of all types. The program of such Data Center shall be designed to (1) provide an accurate nationwide analysis of the fire problem, (2) identify major problem areas, (3) assist in setting priorities, (4) determine possible solutions to problems, and (5) monitor the progress of programs to reduce fire losses. To carry out these functions, the Data Center shall gather and analyze-

(1) information on the frequency, causes, spread, and extinguishment of fires;

(2) information on the number of injuries and deaths resulting from fires, including the maximum available information on the specific causes and nature of such injuries and deaths, and information on property losses;

(3) information on the occupational hazards faced by firefighters, including the causes of deaths and injuries arising, directly and indirectly, from firefighting activities; 
(4) Information on all types of firefighting activities, including inspection practices;

(5) techn: $=21$ information related to building construction, fire properties of materials, and similar information;

(6) information on fire prevention and control laws, systems, methods, techniques, and administrative structures used in foreign nations;

(7) information on the causes, behavior, and best method of control of other types of fire, including, but not limited to, forest fires, brush fires, fire underground, oil blow-out fires, and waterborne fires; and

(8) such other information and data as is deemed useful and applicable.

(b) MerHods.-In carrying out the program of the Data Center, the Administrator is anthorized to-

(1) develop standardized data reporting methods;

(2) encourage and assist State, local, and other agencies, public and private, in developing and reporting information; and

(3) make full use of existing data gathering and analysis organizations, both public and private.

Information d1s- (c) Dissemination.-The Administrator shall insure disseminasomination. tion to the maximum extent possible of fire data collected and developed by the Data Center, and shall make such data, information, and analysis available in appropriate form to Federal agencies, State and local governments, private organizations, industry, business, and other interested persons.

\section{MASTER PLANS}

15 USC 2209.

Sec. 10. (a) General. - The establishment of master plans for fire prevention and control are the responsibility of the States and the political subdivisions thereof. The Administrator is authorized to encourage and assist such States and political subdivisions in such planning activities, consistent with his powers and duties under this Act.

(b) REPORT.-Four years after the date of enactment of this Act, the Secretary shall submit to the Congress a report on the establishment and effectiveness of master plans in the field of fire prevention and control throughout the Nation. Such report shall include, but need not be limited to-

(1) a summary of the extent and quality of master planning activities;

(2) a summary and evaluation of master plans that have been prepared by States and political subdivisions thereof. Such summary and evaluation shall consider, with respect to each such plan (A) the characteristics of the jurisdiction adopting it, including, but not limited to, density and distribution of population; ratio of volunteer versus paid fire services; geographic location, topography, and climate; Fer capita rate of death and property loss from fire; size and characteristics of political subdivisions of the governmental units thereof; and socio-economic composition; and (B) the approach to development and implementation of the master plans:

(3) an evaluation of the best approach to the development and implementation of master plans (e.g., central planning by a State agency, regionalized planning within a State coordinated by a State agency, or local planning supplemented and coordinated by a State agency);

(4) an assessment of the costs and benefits of master plans;

(5) a recommendation to Congress on whether Federal financial assistance should be authorized in order that master plans can be developed in all States; and 
(6) a model master plan or plans suitable for State and local implementation.

(c) Definition.-For the purposes of this section, a "master plan" is one which will result in the planning and implementation in the area involved of a general program of action for fire prevention and control. Such master plan is reasonably expected to include (1) a survey of the resources and persommel of existing fire services and an analysis of the effectiveness of the fire and building codes in such area; (2) an analysis of short and long term fire prevention and control needs in such area; (3) a plais to meet the fire prevention and control needs in such area; and (4) an estimate of cost and realistic plans for financing the implementation of the plan and operation on a continuing basis and a summary of problems that are anticipated in implementing such master plan.

\section{REIMBURSEMENT FOR COSTS OF FIREFIGHTING ON FEDERAL PROPERTY}

Sec. 11. (a) Claim.-Each fire service that engages in the fighting of a fre on property which is under the jurisdiction of the United States may file a claim with the Administrator for the amount of direct expenses and direct losses incurred by such fire service as a result of figiting such fire. The claim shall include such supporting information as the Administrator may prescribe.

(b) Determination.-Upon receipt of a claim filed under subsection (a) of this section, the Administrator shall determine-

(1) what payments, if any, to the fire service or its parent juris-

diction, including taxes or payments in lieu of taxes, the United States has made for the support of fire services on the property in question;

(2) the extent to which the fire service incurred additional firefighting costs, over and above its normal operating costs, in connection with the fire which is the subject of the claim; and

(3) the amount, if any, of the additional costs referred to in paragraph (2) of this subsection which were not adequately covered by the payments referred to in paragraph (1) of this subsection.

(c) Payment.-The Secretary shall forward the claim and a copy of the Administrator's determination under subsection (b) (3) of this section to the Secretary of the Treasury. The Secretary of the Treasury shall, upon receipt of the claim and determination, pay such fire service or its parent jurisdiction, from any moneys in the Treasury not otherwise appropriated but subject to reimbursement (from any appropriations which may be available or which may be made available for the purpose) by the Federal department or agency under whose jurisdiction the fire occurred, a sum no greater than the amount determined with respect to the claim under subsection (b) (3) of this section.

(d) Adjtrdicatron.- - In the case of a dispute arising in connection with a claim under this section, the Court of Claims of the United States shall have jurisdiction to adjudicate the claim and enter judgment accordingly.

$$
\text { REVIEW OF CODES }
$$

Sec. 12. The Administrator is authorized to review, evaluate, and suggest improvements in State and local fire prevention codes, building codes, and any relevant Federal or private codes and regulations. In evaluating any such code or codes, the Administrator shall consider the human impact of all code requirements, standards, or provisions

State-1008l f1ro provention oodes, revier.

15 USC 2211. 
in terms of comfort and habitability for residents or employees, as well as the fire prevention and control value or potential of each such requirement, standard, or provision.

\section{FIRE BAFETY EFTECTIVENESS BTATEMENTS}

25 USC 2212.

Szc. 13. The Administrator is authorized to encourage owners and managers of residential multiple-unit, commercial, industrial, and transportation structures to prepare Fire Safety Effectiveness Statements, pursuant to standards, forms, rules, and regulations to be developed and issued by the Administrator.

\section{ANNUAL CONFERENCE}

15 USC 2213.

Src. 14. The Administrator is authorized to orgunize, or to participate in organizing, an annual con ference on fire prevention and control. Fe nuy puy, in whole or in part, the cost of such conference and the expenses of some or all of the participants. All of the Nation's fire services shall be eligible to send representatives to each such conference to discuss, exchange ideas on, and participate in educational programs on uew tecliniques in fire prevention and control. Such conferences shall be open to the public.

\section{I'UILIC SAFETY AWARDS}

15 USC 2214.

Sec. 15. (a) Establishment.-There are hereby estublished two r.lasses of honorary awards for the recognition of outstanding and distinguished service by public sa fety officers-

(1) the President's Award For Outstanding Public Safety Service ("President's $\Lambda$ ward") ; and

(2) the Secretary's Award For Distinguished Public Safety Service ("Secretary's A ward").

(b) Descrimtion.- (i) The President's A ward shall be presented by the President of the United States to public safety officers for extraordinary valor in the line of duty or for outstanding contribution to public safety.

(2) The Secretary's Award shall be presented by the Secretary, the Secretarv of Defense, or by the Attomey General to public safety officers for distinguished service in the field of public safety.

(c) Selection.-The Secretary, the Secretary of Defense, and the Attorney General shall advise and assist the President in the selection of individuals to whom the President's Award shall be tendered and in the course of performing such duties they shall seek and review nominations for such awards which are submitted to them by Federal, State, county, and local government officials. They shall annually transmit to the President the names of those individuals determined by them to merit the award, together with the reasons therefor. Recipients of the President's Award shall be selected by the President.

(d) Limitation.- (1) There shall not be presented in any one calendar year in excess of twelve President's Awards.

(2) There shall be no limitation on the number of Secretary's Awards presented.

(e) Award.- (1) Each President's Award shall consist of(A) a medal suitably inscribed, bearing such devices and emblems, and struck from such material as the Secretary of the Treasury, after consultation with the Secretary, the Secretary of Defense, and the Attorney General deems appropriate. The Secretary of the Treasury shall cause the medal to be struck and furnished to the President; and

(B) an appropriate citation. 
(2) Each Secretary's Award shall consist of an appropriate citation.

(f) Regulatrons.-The Secretary, the Secretary of Defense, and the Attorney General are authorized and directed to issue jointly such regulations as may be necessary to carry out this section.

(g) Deminrtions.-As used in this section, the term "public safety "Publio safety officer" means a person serving a public agency, with or without of floor." compensation, us -

(1) a firefighter;

(2) a law enforcement officer, including a corrections or court officer; or

(3) a civil defense officer.

\section{INNUAI، RHPORT}

Swo. 16. 'The Secretary shall report to the Congress and the President Report to not later than June 30 of the year following the date of enactment of Congress and this Act and each year therea fter on all activities relating to fire prevention and control, and all measures taken to implement and carry out this Act during the preceding calendar year. Such report shall include, but need not be limited to-

(a) a thorongh appraisal, including statistical analysis, estimates, and long-term projections of the human and economic losses due to fire;

(b) a survey and summary, in such detail as is deemed advisable, of the research and technology program undertaken or sponsored pursuant to this Act;

(c) a summary of the activities of the Academy for the preceding 12 months, including, but not limited to-

(1) an explanation of the curriculum of study;

(2) a description of the standards of admission and performance;

(3) the criteria for the a warding of degrees and certificates; and

(4) a statistical compilation of the number of students attending the Academy and receiving decrrees or certificates;

(d) a sunmary of the activities undertaken to assist the Nation's fire services;

(e) a summary of the public education programs undertaken;

(f) an analysis of the extent of participation in preparing and submitting Fire Safety Effectiveness Statements;

(g) a summary of outstanding problems confronting the administration of this Act, in order of priority ;

(h) such recommendations for additional legislation as are deemed necessary or appropriate; and

(i) a summary of reviews, evaluations, and suggested improvements in State and local fire prevention and building codes, fire services, and any relevant Federal or private codes, regulations, and fire services.

\section{AUTHORIZATION OF APPROPRIATIONS}

SEC. 17. There are authorized to be appropriated to carry out the 15 USC 2216. foregoing provisions of this Act, except section 11 of this Act, such sums as are necessary, not to exceed $\$ 10,000,000$ for the fiscal year ending June 30, 1975, and not to exceed $\$ 15,000,000$ for the fiscal year ending June $30,1976$.

\section{FIRE RESEARCH CENTER}

SEc. 18. The Act of March 3, 1901 (15 U.S.C. 278), is amended by striking out sections 16 and 17 (as added by title I of the Fire Preven- 
15 USC 278r, 2788. Establ1shment. 15 USC $278 r$. tion and Control Act of 1968) and ly inserting in lieu thereof the following new section:

"SEc. 16. (a) There is hereby established within the Department of Commerco a Fire Research Center which sliall have the mission of performing und supporting research on all aspects of fire with the ain of providing scientific and technical knowledge applicable to the prevention and control of fires. The content and priorities of the research program shall be deternined in consultation with the Administrator of the National Fire Prevention and Control Administration. In implementing this section, the Secretary is authorized to conduct, directly or through contracts or grants, a fire research program, including-

"(1) hasic and applied fire resen'ch for the purpose of arriving at an understanding of the fundamental processes underlying all aspects of fire. Such resea rch shall include scientific investigations of-

"(A) the physics and chemistry of combustion processes;

"(B) the dynamics of flame ignition, flame spread, and flame extinguishment;

"(C) the composition of combustion products developed by various sources and under various environmental conditions;

"(D) the early stages of fires in buildings and other structures, structural subsystems and structural components in all other types of fires, including, but not limited to, forest fires, brush fires, fires underground, oil blowout fires, and waterborne fires, with the aim of improving early detection capability;

"(E) the behavior of fires involving all types of buildings and other structures and their contents (including mobile homes and highrise buildings, construction materials, floor and wall coverings, coatings, furnishings, and other combustible materials), and all other types of fires, including forest fires, brush fires, fires underground, oil blowout fires, and waterborne fires;

"(F) the unique fire hazards arising from the transportation and use, in industrial and professional practices, of combustible gases, fluids, and materials;

"(G) design concepts for providing increased fire safety consistent with habitability, comfort, and human impact in buildings and other structures; and

" $(H)$ such other aspects of the fire process as may be deemed useful in pursuing the objectives of the fire research program;

"(2) research into the biological, physiological, and psychological factors affecting human victims of fire, and the performance of individual memlers of fire services, including-

"(A) the biological and physiological effects of toxic substances encountered in fires;

"(B) the trauma, cardiac conditions, and other hazards resulting from exposure to fire;

"(C) the development of simple and reliable tests for determining the canse of death from fires;

"(D) improved methods of providing first aid to victims of fires;

"(E) psychological and motivational characteristics of persons who engage in arson, and the prediction and cure of such behavior;

"(F) the conditions of stress encountered by firefighters, the effects of such stress, and the alleviation and reduction of such conditions; and 
"(G) such other biological, psychological, and physiological effects of fire as have significance for purposes of control or preventious of fires; and

"(3) operation tests, demonstration projects, and fire investigations in support of tlie activities set forth in this section.

"The Secretary shall insure that the results and advances arising from the work of the researcli program are disseminated broadly. HIe shall encourage the incorporation, to the extent applicable and practicable, of such results and advances in building codes, fire codes, and other relevant codes, test methods, fire service operations and training, and standards. The Secretary is authorized to encourage and assist in the development and adoption of uniform codes, test methods, and standards aimed at reducing fire losses and costs of fire protection.

"(b) For the purposes of this section there is authorized to be Appropriation. appropriated not to exceed $\$ 3,500,000$ for the fiscal year ending June 30,1975 and not to exceed $\$ 4,000,000$ for the fiscal year ending June 30, 1976."

\section{VICTIMS OF FIRE}

Sec. 19. (a) Promran.-The Secretary of Health, Educatioll, and 42 USC 290a. Welfare shall establish, within the National Institutes of Health and in cooperation with the Secretary, an expanded program of research on burns, treatment of burn injuries, and rehabilitation of victinis of fires. The National Institutes of Health shall-

(1) sponsor and encourage the establishment throughout the Nation of twenty-five additional burn centers, whicl shall comprise separate hospital facilities providing specialized burn treatment and including research and teaching programs, and twenty-five additional burn units, which shall comprise specialized facilities in general hospitals used only for burn victims;

(2) provide training and continuing support of specialists to staff the new burn centers and burn units;

(3) sponsor and encourage the establishment of ninety burn progranis in general hospitals which comprise stafis of burn injury specialists; tims ;

(4) provide special training in emergency care for burn vic-

(5) augment sponsorship of research on burns and burn treatment;

(6) administer and support a systematic program of research collcerning smoke inhalation injuries; and

(7) sponsor and support other research and training programs in the treatment and rehabilitation of burn injury victims.

(b) Authorization of Apropriation.-For purposes of this section, there are authorized to be appropriated not to exceed $\$ 5,000,000$ for the fiscal year ending June 30,1975 and not to exceed $\$ 8,000,000$ for the fiscal year ending June 30, 1976.

\section{PUBLIC ACCESS TO INFORMATION}

SEc. 20. Copies of any document, report, statement, or information 15 USC 2217. received or sent by the Secretary or the Administrator shall be made available to the public pursuant to the provisions of section 552 of title 5, United States Code: Provided, That, notwithstanding the provisions of subsection (b) of such section and of section 1905 of title 18, United States Code, the Secretary may disclose information whiclı concerns or relates to a trade secret-

(1) upon request, to other Federal Government departments and ugencies for official use; 
(2) upon request, to any committee of Congress having jurisdiction over the subject natter to which the information relutes;

(3) in any judicial proceeding under a court order formulated to preserve the confidentiality of such information without impairing the proceedings; and

(4) to the public when le determines such disclosure to be necessary in order to protect leulth and safety after notice and opportunity for comment in writing or for discussion in closed session within fifteen days by the party to which the information pertains (if the delay resulting from such notice and opportınity for consment would not be detrimental to liealth and safety).

\section{AUMINIBTRATIVE PROVISIONS}

Comptroller

General, an$008 s$ to rooords.
Publioation in Foderal Rog1ster.
Sec: 21. (a) Assistance.-Each department, agency, and instrumentality of the executive branch of the Federal Government and each independent regulatory agency of the United States is autlorized and directed to furnish to the $\mathrm{Administrator}$, upon written request, on a reimbursable basis or otherwise, such assistance as the $\mathbf{A d m i n i s t r u t o r}$ deems necessary to carry out his functions and duties pursirant to this Act, including, but not linited to, transfer of personnel with their consent and without prejudice to their position and ratings.

(b) Powens.-With respect to this Act, the Administrator is nuthorized to-

(1) enter into, without regard to section 3709 of the Revised Statutes, as amended (41 U.S.C. 5) such contracts, grants, leascs, cooperative agreements, or other transactions as may be necessary to carry out the provisions of this Act;

(2) accept gifts and voluntary and uncompensated services, notwithstanding the provisions of section 3679 of the Revised Statutes (31 U.S.C. $665(\mathrm{~b})$ ) ;

(3) purchase, lease, or otherwise acquire, own, hold, improve, use, or deal in and with any property (real, personal, or mixed, tangible or intangible), or interest in property, wherever situated; and sell, convey, mortgage, pledge, lease, exchange, or otherwise dispose of property and assets;

(4) procure temporary and intermittent services to the same extent as is authorized under section 3109 of title 5, United States Code, but at rates not to exceed $\$ 100$ a day for qualified experts; and

(5) establish such rules, regulations, and procedures as are necessary to carry out the provisions of this Act.

(c) A DDIT.-The Secretary and the Comptroller General of the United States, or any of their duly authorized representatives, shall have access to any books, documents, papers, and records of the recipients of contracts, grants, or other forms of assistance that are pertinent to its activities under this $\Lambda$ ct for the purpose of audit or to determine if a proposed activity is in the public interest.

(d) InVEntions and Discoveries.-All property rights with respect to inventions and discoveries, which are made in the course of or under contract with any government agency pursuant to this Act, shall be subject to the basic policies set forth in the President's Statement of Government Patent Policy issued August 23, 1971, or such revisions of that statement of policy as may subsequently be promulgated and published in the Federal Register.

(e) Coordination.- To the extent practicable, the Administrator shall utilize existing programs, data, information, and facilities already available in other Federal Government departments and agencies and, where appropriate, existing research organizations, centers, 
and universities. The $\Lambda$ dministrator shall provide liaison at an appropriate organizational level to assure coordination of his activities with State and local govermment agencies. departments, bureaus, or offices encerned with any matter related to programs of fire prevention and control and with private and other Federal organizations and oflices so concerned.

\section{ASSISTANCE TO CONSUMFR PRODUCT SAFETY COMMISSION}

Sec. 22. Upon request, the Arlministrator shall assist the Consunier 25 USC 2219. Product Safety Commission in the development of fire safety standards or codes for consumer products, as defined in the Consumer Product Safety Act (15 U.S.C. 2051 et seq.).

\section{CONFORMING AMENDMENTS}

SEc. 23. Section 12 of the Act of February 14, 1903, as amended (15 U.S.C. 1511), is amended to read as follows:

\section{"BUREAUS IN DEPARTMENT}

"SEc. 12. The following named bureaus, administrations, services, offices, and programs of the public service, and all that pertains thereto, shall be under the jurisdiction and subject to the control of the Secretary of Commerce:

"(a) National Oceanic and Atmospheric Administration;

"(b) United States Travel Service;

"(c) Maritime Administration;

"(d) National Bureau of Standards;

"(e) Patent Office;

"(f) Bureau of the Census;

"(g) National Fire Prevention and Control Administration; and

"(h) such other bureaus or other organizational units as the Secretary of Commerce may from time to time establish in accordance with law."

Approved October 29, 1974.

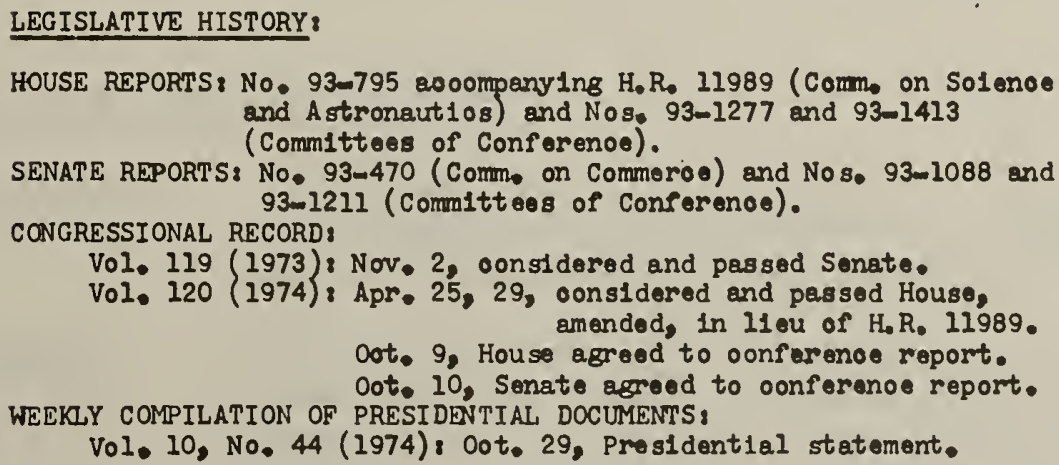



FIRE RISK ANALYSIS

Oobjective: The development of quantitative means to measure and manage fire risk to people, property, or systems frow varlous specifled factors for use by specified decision makers.

'Scope: Since fire and fire loss/cost are random events the desired measures involve probability statements and stochastic processes. Estimates of risk are to be specifled in terms such as likelihood of occurrence and quantiflable loss or cost. Factors giving rise to risk are e1ther controllable or uncontrollable and involve present (1.e. actual or known) or future (1.e. presumed) situations, designs, materlals, procedures, behavior, regulatory requirements, decisions, etc. These tools are Intended for use by code or regulatory officlals, policymakers, corporate managers or others. Typlcal uses of these tools may include the following:

OThe home or bullding owner in selecting from among Elre protection technologies.

OThe building owner or manager in attempting to minimize the total fire and fire protection cost he must bear.

OA code official in interpreting the potential consequences of proposed code changes:

-A state or local governmental offlclal or federal agency manager in developing a rational fire safety strategy for the facilities in his jurisdiction.

Military commander or utility plant operator attempting to mitigate the potential consequences or costs deriving from fire in meeting specifled mission objectives.

OThe professional designer or system developer in understanding the fire risk tradeoffs assoclated with alternative designs or technologles.

\section{FACILITY FIRE SAFETY PERFORMANCE}

Objective:

To develop a consistent system of engineering models for use in predicting the performance of facilitles and people in response to a potential fire.

OScope:

Th1s effort focuses on development of applied fire protection englneering systems, models, and tools targeted for the practicing qualified professlonal engineer. It utilizes the state-of-the-art in scientific knowledge, physical property data, empirical results from tests, fire experience and sound engineering practice. 
It Involves development of a framework and macro models for the development and/or evaluation of active and passive systems for facility fire protection. It draws heavily on closely related activities in the areas of risk appralsal and on fire growth processes, suppression and extinguishment, smoke and toxic gases and bullding and human response. Its principal constituents are fire protection englneers, archltect/engineers, fire

protection systems equiprent and material manufacturers.

\section{SUPPRESSION AND EXTINGUISHMENT}

Oobjective: To estabtish a bas1s for the technologies of extingulshrent and suppression of fire processes through development of an understanding of how flames and smoldering are quenched, development of means to evaluate the effectiveness of materlals or systems designed for this purpose, and development of performance data and test methods.

'Scope: This effort Involves studies of the basic phenomenology of extinction, studies of model systems, and mechanical testing of realistic configurations. The task involves fundamental studies, mathematical and computer models, and substantlal experimental and laboratory effort. Princlpal emphasis is upon solid fuels, although gases and llquids will be 1ncluded. The work treats both smoldering and flaming combustion and Includes liquid, gaseous and solid powder suppressants. Suppression and extingulshment mechanisms are considered at all phases of the fire development process. Integrated results should be sufficlent to serve as technical basis for advancing the state of englneering practice in the development, design, selection, and performance evaluation of a wide varlety of types of fixed or portable extingulshment/suppression systems.

SMOKE AND TOXIC GASES

Objective: To provide an understanding of the rate of production, propertles, and spread of smoke and toxlc gases from fires and the technical basis for control of these products to enable reduction of their harmful 1mpacts particularly on people in fire situations.

Scope: This task covers control of smoke and toxic gases in and around facilities involved in fire. It includes the studies of the properties of combustion products and entrained materlals and thetr effects on the factlity and 1ts occupants. It includes the development of models of smoke generation and transport in facllities, development of quantitative means to assess the 1mpact of smoke and 
toxlc gases under assumed fire and occupant conditions in specifled facilitles; and models for the development and performance evaluation of alternative strategles or technologles for smoke control, for detection and communication systems design, and for predtcting avallable egress time for occupants.

\section{FIRE GROWTH PROCESSES}

Objective: To provide predictive formulae for conponents of fire growth processes, and a series of procedural methods or models and conputer programs for predicting the growth and extinction of fires both inside and outside bullding, facilities, rstructures, vehicles, etc.

Scope:

Fire growth processes can be predicted ut1lizing mathematical techniques, experimental studies and correlations, physical siqulations and combinations of these techniques. The task addresses heat transfer and fluid mechanics of fires, all elements of the fire development process (ignitton, spread, burning rate, growth and extinction). The task involves development of a consistent framework of parameters and notation, data, and computer-based models. The systems model includes "fleld" and "zone" modeling techniques.

\section{MATERIAIS FIRE PROPERTIES}

Objective:

To develop and validate measurement methods and data necessary to characterize the fire performance of materials in engineering applications or useful in the modeling of fires.

${ }^{\text {OScope: }}$

This task involves significant effort in materials sclence, measurement technology development, and experimental work covering the behavior and response of materials to the range of energy sources encountered in Incipient and fully developed fires. Natertals include single substances and combinations. Test methods relate to actual materlals and realistic configurations and conditions and cover a varlety of scales from bench to full-scale.

The outputs from this task represent cruclal inputs to the fire processes and other modeling activities of the fire protection engineering thrusts of the Center. Therefore, very close coordination with these tasks is required in establishing clear definition of key technical parameters, their means of measurement, the kinds of data collected, and relative priortties among the test method development and data generation elements of this task. 
FUNDAMF,NTAL RESEARCH

Objectlve: To develop fundamental sclentiflc knowledge of the pertinent phenomenology of processes that occur in fire and provide the fundamental basts of fire science for the more applied fire protection engincering thrusts of the program.

Scope: This work is scientiflc not empirtcal. It embraces broad areas underpinnting CFR programs whth focused study in the areas of materlals degradation, hot gas physics and chemistry and radiation. Efforts are directed towards Improved understanding of the chemical and physical processes which underlie, macroscopic fire phenomena and Include development of "new techniques and methods for studying these processes.

\section{FIRE TOXICOLOGY}

Objective: To identify potentially harmful combustion products and measure their effect on living organisms.

Scope: This task determines composition of potentlally toxic combustion products under different fire exposures, establishes the physiological effects of such products, and provides measurement methods.

\section{FIRE PERFORMANCE \& VALIDATION}

Objective: To design and conduct tests to evaluate fire performance of systems, components and structures.

Scope: This task includes two important efforts: First, the conduct of unique, highly instrumental experiments to establish fire behavior on a realistic scale. Second, the conduct of validation programs in collaboration with other groups. This task provides particular expertise in facility fire test experimental design, instrumentation and data processing and analysis. 
NBS.114A (REV. 2.80)

\begin{tabular}{|c|c|c|c}
\hline U.S. DEPT. OF COMM. & 1. PUBLICATION OR & 2. Performing Organ. Report No. & 3. Publication Date \\
BIBLIOGRAPHIC DATA & $\begin{array}{c}\text { REPORT NO. } \\
\text { NBSIR 83-2775 }\end{array}$ & & October 1983 \\
SHEET (See instructions) & PSIR
\end{tabular}

SHEET (See instructions)

4. TITLE AND SUBTITLE

A Record of the papers to be presented at the Conference on Standards, Measurements, Quality Control and Production for Economic Support and Growth to be held in Cairo, Egypt, October 29-31, 1983.

5. AUTHOR(S) Ernest Ambler, Charles G. Culver, Rlchard Goodemote, John L. Donaldson, Richard Ronk, Jack E. Snell, S. D. Rasberry, and Kurt F. J. Helnrich

6. PERFORMING ORGANIZATION (If joint or other than NBS, see instructions)

NATIONAL BUREAU OF STANDARDS

DEPARTMENT OF COMMERCE

WASHINGTON, D.C. 20234

9. SPONSORING ORGANIZATION NAME AND COMPLETE ADDRESS (Street, City, Stote, ZIP)

Agency for International Development

Department of State

Washlington, D. C. 20523

10. SUPPLEMENTARY NOTES

Document describes a computer program; SF-185, FIPS Software Summary, is attached.

11. ABSTRACT (A 200-word or less factual summary of most significant information. If document includes a significant bibliography or literature survey, mention it here)

A serles of lectures were glven by the U.S. particlpants in the Conference on Standards, Measurements, Quality Control and Production for Economic Support and Growth, within the framework of the cooperation of NBS with Egyptian Institutions. The Egyptian Institutions Involved are the Egyptian National Institute for Standards, the Egyptian Organization for Standardization and Quality Control, and the Office of Welghts and Measures. MBS proposed the Conference In order to explain the Importance of standards, calibration and reference materials to Egyptian Industrial and government officlals. The Conference also provides a forum for describing the U.S. standards and quality control system.

12. KEY WORDS (Six to twelve entries; alphabetical order; capltalize only proper names; and separate key words by semicolons) AID; calibration, certificat1on; Egypt; fire research; measurements, qual1ty control; reference materials

13. AVAILABILITY

$\square$ Unlimited

X For Official Distribution. Do Not Release to NTIS

$\square$ Order From Superintendent of Documents, U.S. Government Printing Office, Washington, D.C. 20402.

14. NO. OF

PRINTED PAGES

Order From National Technical Information Service (NTIS), Springfield, VA. 2216I 

